\title{
Review
}

\section{Myokines in Appetite Control and Energy Balance}

\author{
Andrew Grannell ${ }^{1,2, *}$, Alexander Kokkinos ${ }^{3}$ and Carel W. le Roux ${ }^{1}$
}

1 Diabetes Complications Research Centre, Conway Institute, School of Medicine and Medical Sciences, University College Dublin, D04 V1W8 Dublin, Ireland; carel.leroux@ucd.ie

2 MedFit Proactive Healthcare, Blackrock, A94 A0D0 Dublin, Ireland

3 First Department of Propaedeutic Internal Medicine, School of Medicine, National and Kapodistrian University of Athens, 15772 Athens, Greece; rjd@otenet.gr

* Correspondence: agrannell@medfit.ie

\section{check for}

updates

Citation: Grannell, A.; Kokkinos, A.; le Roux, C.W. Myokines in Appetite Control and Energy Balance. Muscles 2022, 1, 26-47. https://doi.org/ $10.3390 /$ muscles 1010003

Academic Editor: Corrado Angelini

Received: 8 December 2021

Accepted: 27 January 2022

Published: 30 January 2022

Publisher's Note: MDPI stays neutral with regard to jurisdictional claims in published maps and institutional affiliations.

Copyright: (C) 2022 by the authors. Licensee MDPI, Basel, Switzerland. This article is an open access article distributed under the terms and conditions of the Creative Commons Attribution (CC BY) license (https:// creativecommons.org/licenses/by/ $4.0 /)$.

\begin{abstract}
Efficacy of obesity treatments varies between individuals, highlighting the presence of responders and non-responders. Whilst exercise alone or exercise combined with diet leads to underwhelming weight loss for most, there exist super responders losing significant weight. Furthermore, in response to weight loss, the majority but not all patients tend to regain weight. Within the biopsychosocial model, biology as a determinant of response has been underappreciated. The understanding of the role that organs beyond adipose tissue and the gastrointestinal tract play in appetite control and body weight regulation has developed in recent years. The aim of this review is to highlight potential myokines that may be important in appetite physiology and overall energy balance. A number of attractive targets are described that warrant further investigation. A deeper understanding of how these myokines may drive feeding behaviours has the potential to improve measures to prevent and treat obesity through a precision medicine approach.
\end{abstract}

Keywords: myokines; obesity; appetite; energy balance; body weight regulation

\section{Introduction}

Excess weight (overweight and obesity) is associated with negative health outcomes and places significant economical strain on healthcare systems [1]. Despite that obesity is declared a disease, people living with obesity experience stigma which leads to further negative health outcomes [2]. Typically, body mass index is used to diagnose overweight and obesity, yet this is a poor indicator of health status. A simplistic description leads to a simplistic understanding and given suggestions that body weight can be easily controlled, narratives of personal responsibility related to excess weight are commonplace [3]. The two-stage naturalistic approach to conceptualizing disease begins with the identification of a biological malfunction followed by a normative judgement [4]. The malfunction is a deviation from normal physiology, and the normative judgement is a means of examining the effect of this malfunction on suffering. Excess weight commonly seen in overweight, monogenetic and common obesity typically involves malfunction of normal physiology and suffering in the short or long term [5]. A central feature of the disease is thought to be dysfunction of normal appetite control which can occur in the gut [6], adipose tissue [7] and brain [8]. With appetite control central to our understanding of body weight regulation, there is a need to develop our understanding of basic physiology related to this system. Development of this understanding can improve how excess weight is prevented and treated.

Within traditional models of energy balance and appetite control, adipose tissue has been positioned as the primary peripheral organ directing feeding behaviours through its actions on sub-cortical regions of the brain, including the hypothalamus and brainstem. Here, the hormone leptin is an indicator of long-term energy stores and as a result facilitates the appropriate regulation of energy intake and expenditure [9]. With circulating 
leptin reflective of an individual's fat mass (FM), feeding behaviours are influenced by fluctuations in FM. In response to FM loss, reductions in leptin are detected by the central nervous system, leading to a decrease in energy expenditure [10] and an increase in hunger [11]. In response to an increase in FM and thus leptin, satiety is amplified along with energy expenditure [12]. However, the effects of leptin appear primarily unidirectional, as adaptive responses to weight gain appear transient or ineffective as reflected in the global obesity epidemic, whereas weight loss appears to elicit strong persistent adaptive responses. Collectively, the traditional model of appetite control suggests that leptin is the strongest determinant in the drive to eat, acting in a tonic manner, with gastrointestinal peptides concurrently acting to episodically start and stop feeding [13]. Recent evidence suggests that this model of appetite control may be incomplete, as overall energy expenditure, skeletal muscle and additional organs within the fat-free mass (FFM) compartment also appear to signal to the brain a drive to eat.

Cross-sectional research accumulating since 2012 has shown that in non-dieting individuals, FFM is positively associated with both energy intake and hunger across a range of body mass indexes (BMI) $[13,14]$. Data from these studies reveal that for lean individuals, FM is negatively associated with energy intake whilst at higher BMIs, no association is present. This drive to eat, associated with FFM, appears to be a result of energy expenditure $[15,16]$ and in particular the utilisation of adenosine triphosphate (ATP) [17]. In light of these findings, the model of energy balance and appetite control has shifted from an adipostat construct to an all-encompassing framework with respect to body composition and energy utilisation. Here, energetic demands associated with basal metabolism, physical activity and non-physical activity behaviours stimulate hunger, whilst leptin informs the brain of long-term energy stores within adipocytes, directing behaviours accordingly. With gastrointestinal peptides starting and stopping feeding in conjunction with energy expenditure, including FFM and FM signals, a more complete model of appetite has recently been developed. This model now places the spotlight on the role that skeletal muscle plays in appetite regulation and overall energy balance in non-dieting individuals and in response to weight loss. Given that muscle, as an organ, has typically not been considered to play a role in the physiology of feeding behaviours, there may be unexplored opportunities for the treatment of obesity.

The aim of this narrative review is to examine the role that myokines may play in appetite control and overall energy balance via their interaction with the brain as it pertains to the promotion and suppression of food intake and energy expenditure. As developments are still in their early stages, some aspects of this discussion will be speculative, with the objective of stimulating novel hypotheses. The search strategy included the terms: appetite, overweight, obesity, bariatric, exercise, weight loss, arcuate nucleus, hypothalamus, muscle, myokine. The search was completed in Medline, SPORTDiscus, CENTRAL and EMBASE. Both animal and human studies were included and appropriately discussed in the manuscript. Reference lists from key studies were further examined to highlight literature pertinent to the aims of this paper.

\section{Exercise and Body Weight Regulation}

Whilst the potential involvement of skeletal muscle in body weight regulation is a relatively novel concept, earlier research supports this hypothesis. In 1956, Jean Mayer and colleagues examined the association between physical activity, calorie intake and body weight in factory workers [18]. In those with moderate to high levels of physical activity, energy intake was coupled with energy expenditure, indicating weight stability. In contrast, this coupling was not present where individuals had sedentary jobs. Instead, these individuals were heavier and tended to consume energy beyond daily metabolic requirements, indicating a vulnerability to weight gain. This early finding pointed towards potential physical activity and thus muscle-related factors which might influence feeding behaviours and thus body weight regulation. 
Beaulieu et al. conducted a systematic review of the literature to examine the role of physical activity on appetite regulation [19]. A similar finding to the Jean Mayer study emerged in that a coupling between energy expenditure and energy intake was apparent, where individuals had medium, high and very high levels of physical activity. At low levels of physical activity, energy intake appeared uncoupled from energy expenditure. Furthermore, evidence from this systematic review showed that in response to a covert high energy preload, active individuals appear better able to compensate at a follow-up test meal. That is, sedentary individuals may have diminished appetite sensitivity with a vulnerability to weight gain, highlighting that exercise potentially plays a key role in appetite control.

Exercise is a contentious topic in obesity research, which is not surprising considering it is typically perceived as a strong determinant of weight loss [3,20]. This belief persists despite empirical evidence revealing that isolated high volume aerobic exercise leads to only $1.6 \mathrm{~kg}$ weight loss on average [21]. This limited response may be explained by the fact that energy expenditure and thus ATP utilisation drives energy intake such that any increase in physical activity may stimulate compensatory subtle adjustments in caloric intake [22]. In addition, total daily energy expenditure may be physiologically constrained [23]. What merits consideration however is the examination of individual changes to these interventions as opposed to the group average. Gibbons et al. found that in response to isolated aerobic exercise, responders on average lost $-3.6 \mathrm{~kg}$ in comparison to non-responders. Here, baseline GLP-1 and ghrelin appeared to be determinants of a favourable response [24]. This inter-individual response was captured by King et al., who showed aerobic exercise response ranged from -14.7 to $+1.7 \mathrm{~kg}$ [25]. Clearly, a heterogenous physiological response to exercise may be causal.

For individuals who have lost a substantial amount of weight, exercise is associated with weight loss maintenance [26]. A strong association exists between exercise and weight stability, whilst some individuals respond to exercise with significant weight loss. However, the group average suggests that for most, this is an ineffective tool to elicit substantial weight changes. There is ultimately a need to pinpoint which muscle and exercise related factors known as myokines may be responsible for determining both weight stability and weight loss. A deeper understanding may enhance the prevention and treatment of deleterious excess FM.

\section{Skeletal Muscle Loss and Weight Regain}

For people living with excess adipose tissue which negatively impacts wellbeing, successful treatment of the disease is typically characterised by a percentage reduction in body weight [27]. Examination of the group average response suggests that the magnitude of weight loss is greatest with bariatric surgery, followed by treatment with medications such as GLP-1 analogues and then lifestyle changes $[5,28]$. Whilst responses differ between treatments, a common theme in response to these interventions is the occurrence of partial weight regain. The weight regain phenomenon remains incompletely understood. Patients typically perceive their weight regain as their own fault and do not cite physiological factors as determinants [20]. Research suggests that changes in gastrointestinal peptides promote an increase in hunger and a reduction in fullness [11], with a reduction in circulating leptin simultaneously amplifying hunger and reducing energy expenditure [12]. This reduction in energy expenditure has been coined adaptive thermogenesis, as the change is beyond what is expected based on the change in lean mass (LM). However, as shown in an analysis of participants within The Biggest Loser competition, weight-stable individuals presented with adaptive thermogenesis after 6 years [29]. Recent reanalysis of these data showed that their adaptive thermogenesis may be as a result of these individuals still remaining involved in high-volume exercise [30]. The reduction in energy expenditure observed was thought to be reflective of constrained daily energy expenditure, suggesting that the presence of adaptive thermogenesis in this context is a benign by-product of exercise. This is suggestive of potential hormonal factors related to exercise being important for weight stability. 
Weight loss results in changes in both FM and LM [31]. The change in LM is determined by the magnitude of weight loss [32]. Importantly, LM, as measured by dual energy X-ray absorptiometry, bioelectrical impedance or air displacement plethysmography, considers organs with high metabolic activity such as the liver, heart, kidneys and skeletal muscle. Utilising magnetic resonance imaging, weight loss has been shown to cause most organs within this lean compartment to reduce in size [33]. The effect of changes in the LM compartment and individual high metabolic organs on weight regain has not received much research interest until recently, despite intriguing experimental data gathered during the Second World War.

The Minnesota Starvation Study led by Dr Ancel Keys took place between 1944 and 1945 [34]. This study provided insights into fundamental physiological mechanisms upregulated by severe weight loss [35]. The purpose of this experiment was to gain insight into the optimal management of victims of conflict-related famine conditions. Lean volunteers lost on average $-24 \%$ of their weight with significant reductions in both FM and LM. Reanalysis of this data by Dulloo et al. showed a preferential restoration of FM as when this tissue returned to baseline levels, LM remained only partially restored [36]. A key observation was that subjects remained hyperphagic in ad libitum conditions until LM was restored, highlighting that LM may interact with the appetite-regulating centres of the brain or may orchestrate feeding behaviour.

Sixty years after the Minnesota study, similar findings regarding the role of LM changes on weight regain have been observed in humans and rodents. Vink et al. found that the percentage of weight loss comprising FFM correlated with regain after an $8-9 \mathrm{~kg}$ weight loss [37]. Turicchi et al. conducted a meta-regression to examine the effects of body composition changes when weight loss was $\geq 5 \%$ and weight regain $\geq 2 \%$ [38]. They found that both FFM and FM predicted weight regain. Examination of the Diogenes data by the same group showed a similar effect [39]. Here, weight loss was on average $11 \mathrm{~kg}$, and changes in FFM predicted weight regain, although gender-specific effects appeared present, with a greater effect for men. Providing deeper insight into potential central mechanisms, Flack et al. examined the effects of 12 weeks of aerobic exercise for weight loss on food reinforcement (wanting for food) via the operate responding task [40]. They found that a reduction in FFM predicted an increase in operate responding for food. Hao et al. examined the effects of bariatric surgery on body composition changes in diet-induced obese rats that were calorie restricted prior to surgery [41]. The body weight of the rats pre-surgery was that of chow controls. Post-surgery, the rats lost additional FM. However, LM was regained to pre-surgical levels, indicating a defence of this tissue.

Whilst the early starvation study suggests a role of LM loss in the weight regain phenomenon, the recent human studies indicate a small effect. Turicchi et al. found that in men, FFM loss accounted for only $4.8 \%$ of the total variance regarding weight regain [39]. However, an important difference between the human studies described above and that of Ancel Keys is that participants were living with obesity, and thus relative to lean individuals, would lose less LM during weight loss [42]. In addition, the magnitude of weight loss in the Minnesota study was almost three times that seen in contemporary observations. Nonetheless, it is important to consider potential physiological signals that may interact with the appetite regulation centres of the brain to restore LM. Whilst the LM compartment as a whole considers several organs which may be important in the regain phenomena, the focus of this review is on skeletal muscle mass.

\section{Myokines, Appetite and Energy Expenditure}

As described above, muscle-related factors known as myokines may play a key role in weight loss, weight loss maintenance and weight regain. Myokines are hormones produced by myocytes, primarily in response to increased energetic demands and during cell proliferation and differentiation. These hormones can act in an autocrine, paracrine and endocrine manner, thus rendering the muscle-brain axis of particular interest to obesity researchers and clinicians. Readers can refer to recent work highlighting the effects of 
myokines on system-wide health gains [43]. In non-dieting individuals, exercised skeletal muscle can interact with the brain [44]. With both potential direct and indirect effects on feeding behaviours and energy expenditure, this is a field of research that may contribute significantly to the prevention and treatment of obesity.

\subsection{Myokines as Potential Appetite Suppressing Factors}

The interindividual response to exercise from a weight loss and weight loss maintenance perspective is poorly understood. The belief that exercise is a strong weight loss tool is widespread $[3,20]$. As a typical response is characterised by minimal weight loss, this can leave patients with a diminished sense of self-efficacy. Therefore, care is needed when framing the value of exercise to patients. Nonetheless, future precision medicine approaches may have the potential to highlight people who will or will not respond to exercise for weight management. The myokines described standout as potential key determinants of weight management in response to exercise leading to either weight loss or weight loss maintenance (Figure 1).

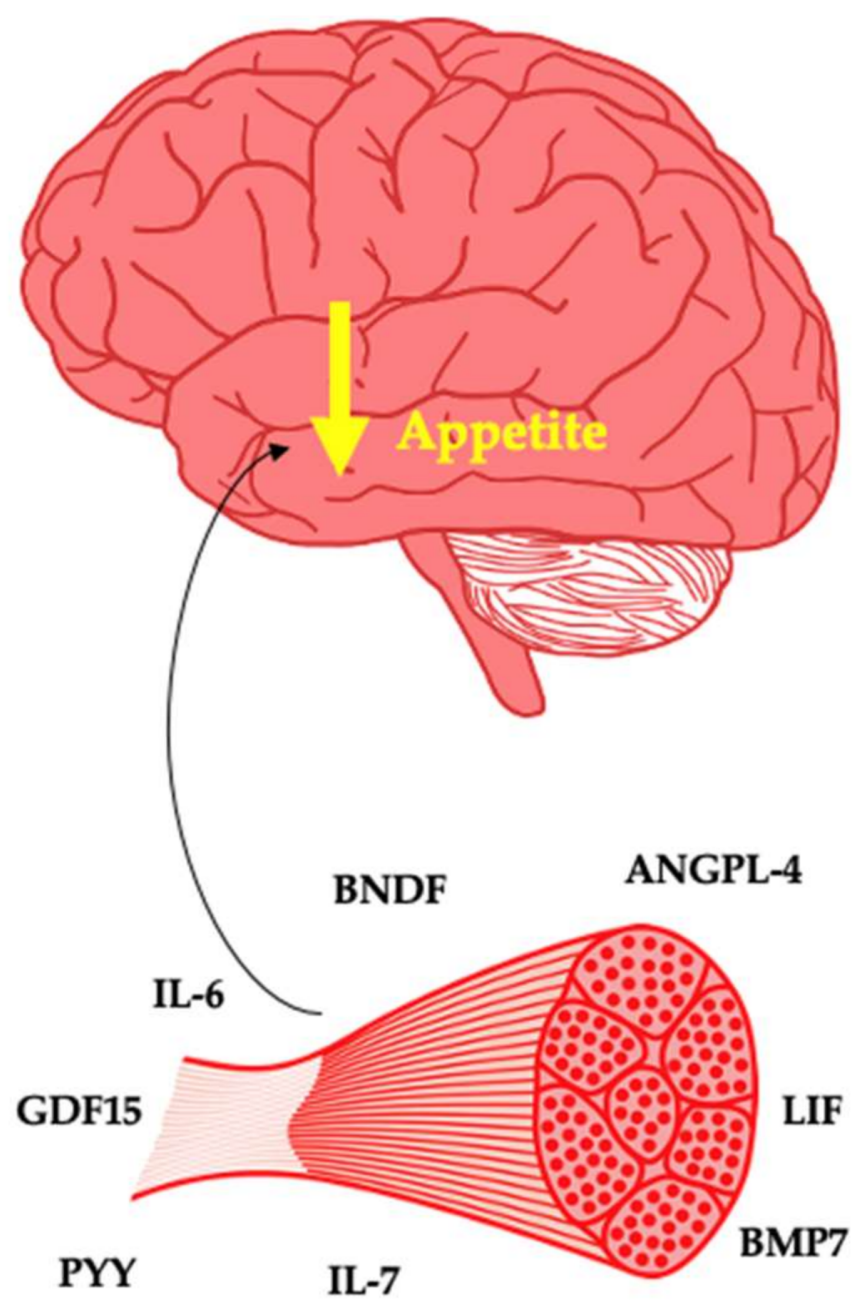

Figure 1. Myokines as potential suppressors of appetite.

\subsubsection{Interleukin-6}

Interleukin-6 (IL-6) is well understood as a pro-inflammatory cytokine. In response to prolonged exercise, changes in the energy sensor AMP-activated protein kinase is associated with IL-6 production by the muscle cell, with up to 100 -fold increases in this myokine during an exercise bout [45]. The indirect effect of muscle on the brain from an appetite perspective is driven by the interaction of IL- 6 with the gastrointestinal tract. IL-6 
increases glucagon-like peptide-1 (GLP-1) production, thus favourably impacting satiety and glycaemic control [46]. Muscle derived IL-6 may directly interact with the brain, as IL-6 receptors are present within the hypothalamus [47]. This is unsurprising, as medications that inhibit IL-6 such as tocilizumab are obesogenic [48]. With IL-6 deletion causing weight gain in mice via increased energy intake [49,50], overexpression of IL-6 in mice imparts an anorectic effect [51] and peripheral and central administration leading to satiety in mice with obesity $[52,53]$. It is clear that IL-6 plays an important role in appetite. These findings from animal studies are of relevance to humans as IL-6 is negatively associated with hunger post exercise [54]. Overall, IL-6 is potentially an important hormone in the regulation of body weight and the pathogenesis of obesity.

\subsubsection{Peptide $Y Y$}

Peptide YY (PYY), similar to GLP-1, is a gastrointestinal peptide that can act on the brain to increase satiety. Exercise has been shown to increase circulating PYY [55,56]. Whilst the mechanism responsible for the increase in PYY after exercise is poorly understood, it has been suggested that IL-6 may act on the L-cells to increase the production of PYY [46,57]. This may be an indirect effect that muscle may have on the brain from an appetite standpoint. Both PYY and its Y receptors are expressed by human skeletal muscle [58]. Whilst the effects of muscle-derived PYY from autocrine, paracrine and endocrine perspective are incompletely understood, basal PYY gene expression may predict the hypertrophic response to resistance training [59].

In people with obesity, PYY is lower than controls and improves in response to bariatric surgery $[6,60]$. Intraperitoneal injection of PYY in rats reduces energy intake, resulting in weight loss. In lean humans, infusions of PYY acutely suppressed energy intake [61]. Exogenous PYY administration improves appetite control in people with obesity with pre-existing attenuated endogenous production [6]. It is therefore important to examine potential inter-individual responses to exercise with regard to PYY production both directly from the myocyte or indirectly via myocyte-derived IL-6. Given the abundance of evidence regarding the effects of PYY on the appetite regulating centres of the brain, it is plausible that muscle may contribute directly or indirectly to circulating concentrations post exercise.

\subsubsection{Brain-Derived Neurotropic Factor}

Brain-derived neurotropic factor (BDNF) is an important biomolecule in appetite control and thus body weight regulation. The receptor for BDNF is widespread within the hypothalamus and within other regions responsible for appetite control [62]. BDNF also acts on the mesolimbic dopamine system to influence hedonic elements of feeding behaviour [63]. Central administration of BDNF promotes weight loss by reducing food intake in animals [64]. Peripheral levels of BDNF are thought to mirror central levels [65]. Knock out of BDNF in animal models leads to hyperphagia and obesity [66]. Mutations of the BDNF receptor in humans have also been linked to rare cases of monogenic obesity [67]. Furthermore, genome-wide association studies show that a single nucleotide polymorphism of BDNF is associated with increased risk of obesity [68].

BDNF mRNA is expressed by skeletal muscle in response to contraction [69] and fasting [70]. However, whether muscle-derived BDNF is released into circulation is not well understood [71]. Meta-analyses has shown that concentrations of BDNF in serum and plasma do not differ between people with obesity and lean individuals [72]. BDNF increases in response to bariatric surgery [73] and aerobic exercise [74], indicating the potential for a muscle-brain link which could shed light on the anorectic effect of bariatric surgery and exercise. With weight loss associated with a reduction in BDNF [75], examining the potential correlation of changes in BDNF with both muscle loss and weight regain is of interest. 


\subsubsection{Interleukin-7}

Interleukin-7 (IL-7) is a cytokine that acts in a pro- and anti-inflammatory manner. IL-7 appears elevated in people with obesity and diabetes, potentially through over secretion by visceral adipose tissue [76]. This is perhaps unsurprising, given that obesity as a disease is characterised by unfavourably high levels of proinflammatory cytokines. The role of IL-7 extends to energy balance and body weight regulation, as exogenous administration suppresses energy intake [77]. IL-7 receptors were found expressed within the arcuate nucleus, with IL-7 administration stimulating the expression of POMC and inhibiting AgRP, thus reducing EI after fasting [77]. Adding further complexity, Lucas et al. found that administration of IL-7 protected against high-fat-diet-associated gains in adipose tissue in rodents [78]. This effect occurred without changes in food intake and likely as a result of changes in adipogenesis, lipogenesis and/or lipolysis.

Germain et al. examined circadian levels of IL-7 in people with anorexia nervosa, constitutional thinness, obesity without metabolic syndrome and controls [79]. Importantly, and in contrast with other studies, IL-7 was reduced in healthy obesity potentially due to an absence of immunological derangements and was higher in constitutional thinness. It is in constitutional thinness that anorectic hormones such as PYY are elevated and that the weight fat setpoint is regulated at a low BMI [80]. This highlights a potential role of IL-7 as a biological determinant of these differing states of body weight seen in obesity and constitutional thinness.

In vitro and in vivo skeletal muscle produces IL-7, which may act on the muscle itself to regulate cell development [81]. After exercise in the form of $90 \mathrm{~min}$ of football, IL-7 is elevated [82] and after 2 weeks of strength training, IL-7 mRNA in skeletal muscle is increased [81]. There is a need to establish the role of IL-7 in acute appetite control in humans and to untangle the changes in IL-7 that occur in response to weight gain that may reflect an adaptive appetitive response and/or changes in immune function. In response to exercise, both acutely and chronically, there is a need to examine how changes in skeletal muscle-derived IL-7 may impact on feeding behaviours. Whilst IL-7 appears to act in a similar manner to IL-6, the literature thus far is confusing.

\subsubsection{Leukaemia Inhibitory Factor}

Leukaemia inhibitory factor (LIF) is a cytokine involved in the proliferation, differentiation and survival of multiple cell types. High fat diet (HFD)-induced obesity in rodents is associated with hypothalamic inflammation, a pathological state that is a key characteristic of the disease. In rodents, LIF is downregulated in both the nucleus tractus solitarus of the brainstem and hypothalamus in response to HFD [83,84]. Importantly, LIF can act upon LIF receptors on POMC neurons in an anorexigenic manner by stimulating the release of alpha MSH [85]. Both central and peripheral administration of LIF in rodents reduces body weight $[84,86,87]$.

LIF as a myokine is thought to play a key role in satellite cell proliferation [88]. mRNA expression of LIF increases after both aerobic and resistance exercise [89,90]. Plasma LIF also increases in response to exercise [91]. Given than LIF can pass through the blood-brain barrier [92], this myokine may play a yet to be appreciated role in appetite control and body weight regulation.

\subsubsection{Angiopoietin-Like Protein 4}

Angiopoietin-like Protein 4 (ANGPL4) is produced by most tissues and in particular plays a role in angiogenesis, metabolism and differentiation [93]. ANGPL4 has also been implicated in lipid metabolism [94]. Kim et al. found that ANGPL4 is expressed within the hypothalamus and increases after food intake [95]. Furthermore, administration of leptin, insulin and nutrients amplified this effect, suggesting that ANGPL4 mediates the effect of these peripheral factors on appetite control. Central administration of ANGPL4 suppressed food intake, leading to reduced body weight and increased energy expenditure with this effect mediated by the suppression of AMPK. In ANGPL4 null mice, hypothalamic AMPK 
activity was increased along with body weight as a result of increased food intake and reduced energy expenditure, which was reversed by central administration of ANGPL4.

As a myokine, ANGLP4 is produced by myotubes as a result of stimulation by fatty acids and PPAR-Alpha [96]. Norheim et al. demonstrated that aerobic exercise increased skeletal muscle ANGPL4 mRNA and serum levels [97]. Whilst ANGPL4 is increased in obesity, a finding which may reflect impaired lipid metabolism, it is of interest that postprandially ANGPL4 is secreted by skeletal muscle and adipose tissue [98,99]. It is therefore important to unravel the role that ANGPL4 may play in the regulation of body weight and if skeletal muscle contributes to this effect.

\subsubsection{Bone Morphogenic Protein 7}

Bone morphogenic proteins (BMPs) are growth factors with multiple functions at the cellular, tissue and organ level that appear to play a role in the central regulation of energy balance [100]. BMP7 is produced by skeletal muscle and may directly influence muscle protein synthesis [101]. In mice, ICV administration of BMP-7 and treatment with BMP-7 decreases appetite, leading to weight loss in both models of diet-induced obesity and ob/ob mice, indicating a leptin-independent pathway [102]. The BMP receptor BMPR1A was shown to be colocalised with POMC neurons [103]. Subsequent knock out of BMPR1A in the POMC neurons led to hyperphagia. This is perhaps an unsurprising finding given that polymorphisms of both BMP ligands and receptors, including BMPR1A, have been associated with human obesity $[104,105]$. There is a need to examine in humans the effects of exercise on BMP7, as thus far, only animal studies have highlighted that aerobic exercise increases both BMP7 mRNA and protein in skeletal muscle [106,107].

\subsubsection{Growth Differentiating Factor 15}

Growth differentiating factor 15 (GDF15) is expressed by many tissues, and in healthy individuals, circulates in the bloodstream and appears to play a role in appetite control [108]. In disease states such as cancer, heart failure, chronic kidney disease, obesity and infection, GDF15 increases significantly [109]. This overexpression is associated with a reduction in energy intake in all conditions, with the exception of obesity. GDF15 receptors can be found in the brainstem, specifically the area postrema and nucleus tractus solitarius, which are well established as important regions involved in appetite control [110]. Given that overexpression of GDF15 has been shown in numerous studies to reduce energy intake leading to weight loss, this cytokine may play a key role in appetite control and body weight regulation. Whilst GDF15 is elevated in obesity, knock out of GDF15 has been shown to result in obesity [111]. The weight loss effect of metformin accounts for a significant proportion of its ability to drive health gain, and recently, this was shown to be due to GDF15 (96). With GDF15 being produced by muscle in response to exercise (97), there is a need to further establish a potential anorectic effect that this protein may drive in response to exercise.

\subsubsection{Implications for Obesity as a Disease along with Prevention and Management}

The potential role of the myokines described above in appetite regulation is of particular importance with regard to weight stability, weight loss maintenance and thus obesity prevention and treatment. Exercise and in particular aerobic training is associated with weight stability and weight loss maintenance [26]. For sedentary individuals, exercise alone, on average, has a small effect on body weight [21]. However, when examining individual changes to interventions with increased exercise volume without changes in diet, there are some super responders [25]. From the perspective of precision and personalised medicine, it will be important to predict who will respond favourably to this form of intervention. There is a need to examine the role that appetite-supressing myokines may play in the phenomenon of exercise-induced weight loss and weight stability and identify responders prior to interventions. Overall, this is an area that warrants further 
investigation to enable a better understanding of obesity as a disease and optimization of prevention and treatment strategies.

\subsection{Myokines as Drivers of Energy Expenditure}

Whilst appetite regulating factors are important with regard to energy balance and thus body weight regulation, myokines impacting energy expenditure may also play a key role in body weight regulation (Figure 2). Significant weight loss is not common in response to increased exercise, although some individuals favourably respond to this intervention [25]. In the case of these super responders, myokines that promote energy expenditure may be upregulated. Here, weight loss could occur without changes in feeding behaviours. In addition, with regard to weight stability, both in the context of no prior weight loss and in response to weight loss, some myokines may play a key role and may partly explain the variance seen in the well-established relationships between exercise and body weight maintenance [26].

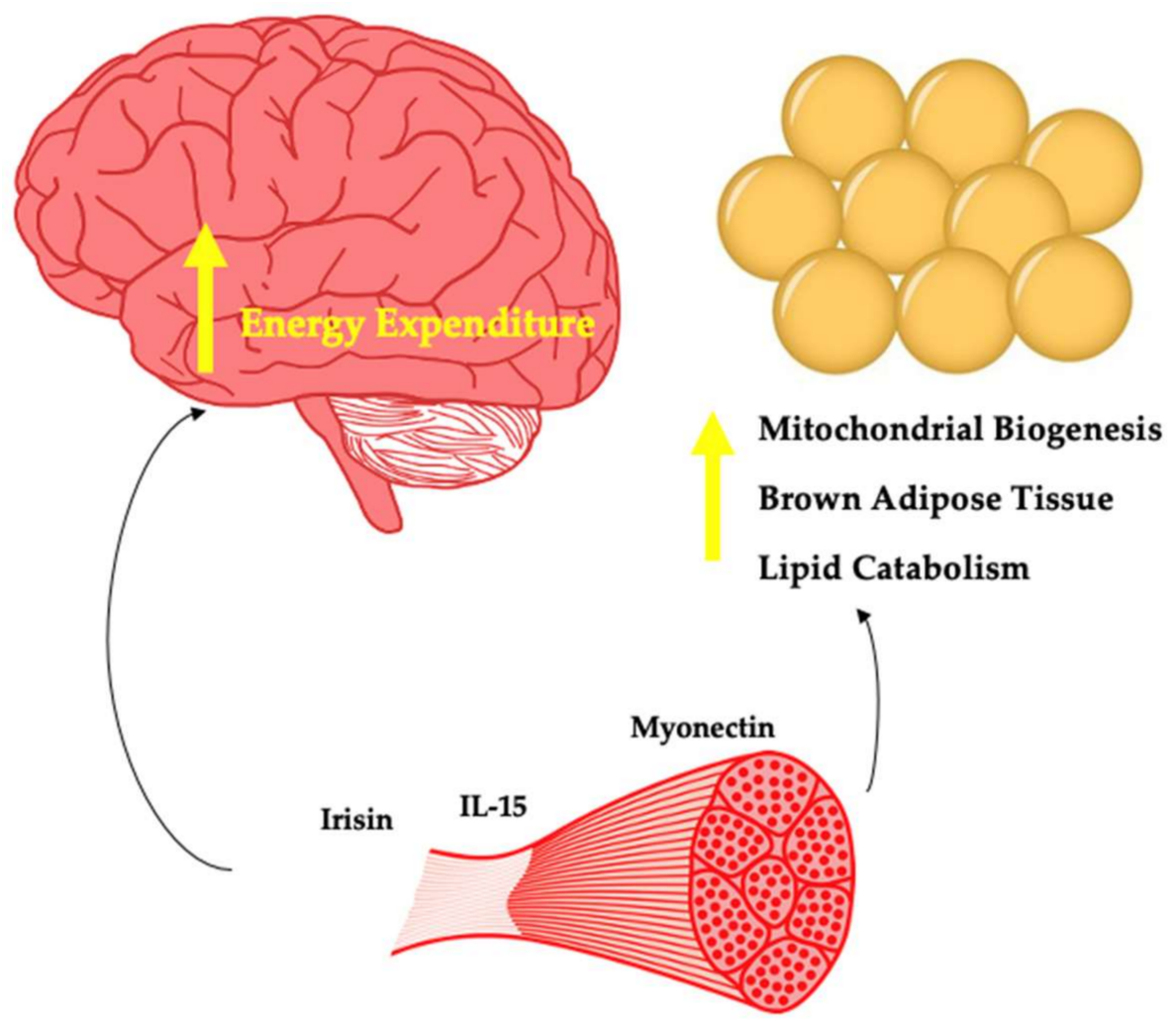

Figure 2. Myokines potentially involved in energy expenditure.

\subsubsection{Irisin}

The transcriptional co-activator PGC1-alpha is produced by muscle in response to exercise and leads to mitochondrial biogenesis along with additional effects directly on the muscle. In 2012, Bostrom et al. found that PGC1-alpha stimulated the expression of the FDNC5 gene that encodes for the novel hormone Irisin [112]. The authors found that increasing plasma irisin levels 3-4 fold led to browning of subcutaneous adipose tissue and weight loss in obese mice. This effect has been captured by several other authors [113]. The findings regarding exercise mode and irisin are mixed. Kim et al. showed that irisin is increased with resistance training but not aerobic training in people with obesity [114]. Timmons et al. revealed no change in irisin after aerobic training [115]. Norheim et al. found no change in irisin with combined aerobic training and resistance training [116]. Both interval and continuous aerobic training were found to increase irisin [117]. The mixed 
findings likely reflect differences in study design, differences in participants (lean vs. with obesity) and inter-individual responses.

Within the brain, Ferrante et al. showed that central administration of irisin reduced energy intake [118]. This effect may emerge due to the co-localisation of irisin and NPY in the paraventricular nucleus. The authors presented evidence to suggest that reduced energy intake was a result of stimulation of CART and POMC neurons. Importantly, most studies show no effect of irisin on feeding behaviours. In addition to reduced energy intake, Ferrante et al. also found that plasma norepinephrine was increased, indicating that irisin may act centrally to increase sympathetic nervous system activity [118]. Thus, a central mode of action may also be responsible for the effect of irisin on increased oxygen consumption. In people with obesity, irisin is reduced [119]. In contrast, Pardo et al. found it to be increased in people with obesity [120]. Given that in these subjects irisin was correlated with resting energy expenditure, it may be that increased muscle in these subjects relative to controls is causal in determining this finding. With bariatric surgery also being shown to increase irisin in one study [121] and with no change found by Demirpence et al. [119], this protein remains important in our understanding of the role of muscle in body weight regulation, which is far from complete.

\subsubsection{Interleukin-15}

Interleukin-15 (IL-15) is a pleiotropic cytokine that plays a key immunological role [122]. Circulating levels of IL-15 increase acutely in response to aerobic and resistance training [123]. Whilst IL-15 is expressed by skeletal muscle, the contribution to circulating levels appears unclear [124]. Treatment of young and elderly myotubes with recombinant IL-15 leads to myogenesis [125]. Anabolic effects of IL-15 on skeletal muscle have also been demonstrated in vivo, as this myokine appears to increase muscle protein synthesis whilst decreasing muscle protein breakdown [126].

In people with obesity, IL-15 is reduced relative to lean individuals [127,128]. A negative association of both muscle IL-15 mRNA and circulating IL-15 vs. both BMI and FM has been observed in humans [129]. In contrast, weight loss decreases IL-15 in people with obesity [130]. This latter finding may reflect an increased proinflammatory state in some individuals living with obesity. Administration of IL-15 for 7 days to rats reduces white adipose tissue [131]. Barra et al. found that overexpression of IL-15 led to a lean phenotype, whilst IL-15 knock-out mice gained weight [127]. The same authors showed that treatment of both IL-15 knock-out mice and diet-induced obesity mice with IL-15 led to weight loss without changes in energy intake. The weight loss effect may be as a result of inhibited lipid deposition in the adipocyte [132]. Almendro et al. found that treatment of rats with IL-15 led to increased fatty acid oxidation in muscle, potentially as a result of the detected increases in the transcription factor PPAR-Delta, which is important in lipid catabolism [133]. Treatment of rats with IL-15 led to a reduction in white and brown adipose tissue with the effect potentially due to upregulation of thermogenic protein mRNA content such as UCP1 and UCP3 [134].

Whilst IL-15 appears to play a key role in body weight regulation, central effects have yet to be determined. IL-15 receptors are expressed in the brain and the biomolecule can cross the blood-brain barrier. Therefore, central effects regarding changes in energy expenditure are possible. In the context of muscle and body weight regulation, the evidence thus far strongly suggests that IL-15 plays a key role in the maintenance of healthy weight in response to exercise and may explain some of the variance with regard to responders to exercise interventions. Specific IL-15 genotypes are associated with favourable training response to aerobic exercise from the perspective of changes in body fat percentage and FFM [135].

\subsubsection{Myonectin}

Whilst the majority of proteins discussed thus far are produced by several cell types in the body beyond muscle, myonectin stands in contrast. As a result of nutrient flux in the 
form of glucose and lipid through muscle cells, myocytes express and secrete myonectin into the circulation as demonstrated by Seldin et al. [136]. In this same study, aerobic exercise in mice led to an increase in myonectin mRNA expression by muscle and an increase in circulating levels. The authors observed myonectin to be reduced in mice with DIO. Investigating the effects of recombinant myonectin on metabolism, it was shown that circulating free fatty acid levels were reduced via promotion of free fatty acid uptake into adipocytes and hepatocytes.

The seminal findings described above highlight a potentially important role of myonectin in body weight control and metabolic function. Li et al. found myonectin to be elevated in older adults with impaired glucose tolerance or type 2 diabetes [137]. The same authors found that exercise did not change circulating myonectin. In contrast, Pourranjbar et al. found that 8 weeks of aerobic exercise in women with obesity increased myonectin and reduced insulin resistance [138]. The mixed findings are likely a result of sampling methods, populations examined, and timing of exercise-related measurements (acute vs. chronic). Recently, Li et al. demonstrated that serum myonectin is lower in people with obesity but increases 6 months post sleeve gastrectomy [139].

Wang found that myonectin-deficient and knock-out mice were heavier than wild-type mice which was not accounted for as a result of changes in food intake [140]. Instead, there was reduced basal energy expenditure. Whilst there is a paucity of data regarding how myonectin influences body weight, it may be due to changes in energy expenditure as demonstrated by Wang [140]. Thus, central changes of myonectin need to be explored. Given the homology of myonectin with adiponectin and the effect of adiponectin on appetite control via interaction with the arcuate nucleus [141], this is a logical target of investigation.

\subsection{Myokines as Potential Appetite Promoting Factors}

Weight regain is a ubiquitous phenomenon of varying magnitude in response to weight loss. The determinants of weight regain are not fully understood. However, biological factors are important, with changes in leptin influencing central appetite control and energy expenditure. In addition, a shift in gastrointestinal tract-derived appetite hormones towards a predominantly orexigenic tone has been observed [11]. Changes in LM are also predictive of weight regain [35]. The changes in LM in response to weight loss reflect a reduced size of various organs, including the heart, liver, kidney and skeletal muscle [33]. The liver has been shown to regenerate after resection [142], highlighting that these organs may have independent mechanisms of regrowth. This review focuses primarily on myokines that may be produced by skeletal muscle in response to weight loss-induced changes that may act on the brain to simulate appetite and thus facilitate restoration of muscle size. Whilst any purported signalling event associated with muscle loss and weight regain until now remains unknown, these myokines present as attractive targets in future investigations (Figure 3). Within the brain, the melanocortin 4 receptor (MC4R) is well understood to regulate the drive to seek and consume energy from the environment. It was recently discovered that MC3R within the hypothalamus plays a key role in growth, sexual maturation and lean mass accretion [143]. It is hypothetically plausible that both MC3R and MC4R coordinate weight regain after intentional weight loss and in doing so orchestrate the return of lean mass to its previous set point through the action of myokines, anabolic factors and appetite hormones.

\subsubsection{Insulin-Like Growth Factor 1}

Insulin-like growth factor 1 (IGF-1) is an anabolic hormone primarily produced by the liver as a result of growth hormone interaction. IGF-1 particularly plays a key role in bone and tissue growth such as skeletal muscle hypertrophy [144]. IGF-1 receptors are found within the arcuate nucleus of the hypothalamus. Both overexpression and ICV administration of IGF-1 leads to an increase in appetite and energy intake [145]. Importantly, IGF-1 is produced by muscle [146]. In people with obesity, despite GH tending 
to be reduced, IGF-1 remains unchanged due to enhanced hepatic GH sensitivity [147]. The interaction of IGF-1 with IGF binding proteins determines its biological activity. The effects of weight loss in humans on IGF-1 vary across studies, making it difficult to draw definitive conclusions [148]. However, it is of interest to examine in particular the effect of body composition changes in serum and skeletal muscle expression of IGF-1 and its binding proteins along with association of these changes with weight regain.

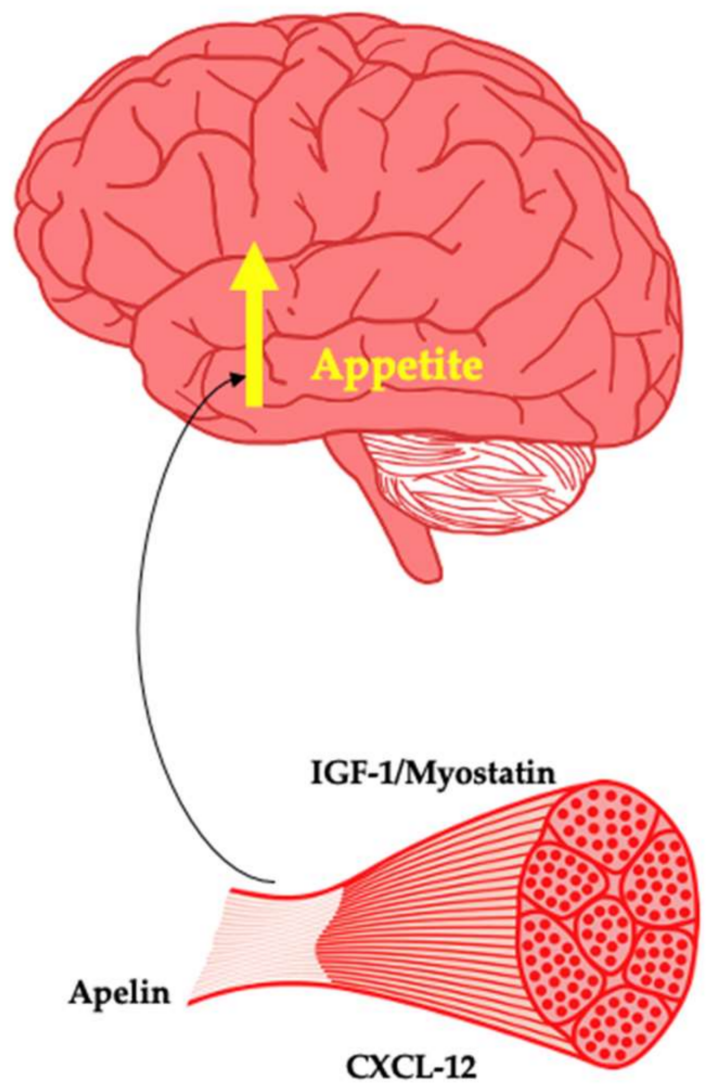

Figure 3. Myokines as potential promoters of appetite.

\subsubsection{Myostatin}

Myostatin is a negative regulator of skeletal muscle mass [149]. Knock out of myostatin or genetic mutations are associated with increased muscularity due to the effects of the biomolecule on muscle proteostasis [150]. Skeletal muscle myostatin mRNA expression has been shown to decrease substantially after bariatric surgery [151]. Fat-free mass loss and myostatin mRNA are correlated after bilio-pancreatic diversion with $45 \%$ weight loss [152]. This likely represents a mechanism attempting to prevent or reverse further muscle loss. Whilst myostatin has yet to be found to interact with the brain, myostatin regulates hepatic IGF-1 [153,154], suggesting a potential signalling system intended to restore muscle loss. Furthermore, in a mouse model of lipodystrophy, the inhibition of myostatin reduces hyperphagia, suggesting a yet to be appreciated role in appetite [155]. Inactivation of myostatin appears to be protective against development of obesity in rodents [156]. Therefore, this myokine warrants significant investigations into the prevention of weight gain and as a potential driver of regain after weight loss from the perspective of appetite control.

\subsubsection{Apelin}

Apelin is an adipokine with pleiotropic effects [157]. Apelin is a prepropeptide that can form several active fragments with varying numbers of amino acids. As a myokine, apelin mRNA increases two-fold in response to aerobic exercise in humans, whilst circulating levels do not change in the resting state post intervention [158]. Investigation of muscle 
biopsies taken from these same participants revealed that apelin was secreted by myotubes with changes in energy status appearing responsible for apelin expression. In people with obesity, apelin is elevated and decreases in response to both aerobic and resistance training in people with obesity [159]. There is a lack of evidence regarding the effects of exercise on apelin in lean individuals.

In the hypothalamus, apelin mRNA and its receptor have been found in the paraventricular and arcuate nucleus. In the context of appetite control, chronic central administration of apelin-13 increased food intake and body weight in rodents [160,161]. In fish, apelin mRNA increased in response to food deprivation, while intraperitoneal injection of apelin increased food intake [162]. In people with obesity and diabetes, apelin is increased, suggesting a potential link to the metabolic syndrome $[163,164]$. Considering the evidence showing an orexigenic effect of apelin, this could also indicate appetite dysfunction. In response to weight loss via exercise, caloric restriction, and bariatric surgery, circulating apelin as measured via RT-PCR was reduced [165]. Prior to bariatric surgery, Soriguer et al. found that in people with severe obesity and diabetes, apelin was higher than controls, whilst this difference was not observed if the patient was not diabetic [166]. After surgery, it was found that apelin was reduced only in these patients with diabetes or impaired fasting glucose.

Apelin is produced by skeletal muscle and appears to act in an orexigenic manner on the brain. As a result, there is a need to elucidate what specific active forms are increased or decreased in response to exercise. In addition, it is of interest to examine the effect of muscle loss as a result of intentional weight loss on apelin expression and on the production of specific active forms. Non-responders to exercise from a weight loss perspective may produce more apelin than responders. Furthermore, apelin may signal muscle loss and act directly on the brain to drive hunger and facilitate muscle regain. Apelin also reduces energy expenditure when centrally administered. Thus, this peptide may provide important insights into obesity pathogenesis [167].

\subsubsection{CXCL-12}

Stromal-derived factor-1 or CXCL-12 is a chemokine that plays an important role in satellite cell activation and thus muscle homeostasis [168]. Obesity is characterised by low grade inflammation. Within the appetite-regulating centres of the brain, this inflammatory milieu is thought to be a distinguishing feature of the disease. CXCL-12 is expressed throughout various regions of the brain, including the hypothalamus [169]. In mice, CXCL-12 is elevated in adipose tissue where it may facilitate inflammation within the adipocyte leading to insulin resistance [170]. Poon et al. examined the effect of HFD on the expression of CXCL-12 and its receptor. Relative to chow, 5 days of HFD led to increased expression and protein level of CXCL-12 and its receptor in the paraventricular nucleus and perifornical lateral hypothalamus [171]. Circulating protein levels of CXCL-12 were also increased. When CXCL-12 was centrally administered, food intake increased, and locomotor activity decreased. This finding highlights how consumption of HFD may lead to pathology in the hypothalamus and may increase the drive to eat.

Given that acute aerobic exercise increased CXCL-12 expression in skeletal muscle of mice [172], there is potential for muscle-brain cross talk from an appetite perspective. In humans, plasma CXCL-12 is increased after cycling [173]. Whilst CXCL-12 has been documented as elevated in an obese state likely as a result of adipose tissue expression, Wolf et al. found CXCL-12 to be lower in people with obesity [174]. Therefore, the metabolic health of the individual may be a determinant in obesity. In response to bariatric surgery, sleeve gastrectomy but not after Roux-en y gastric bypass increases CXCL-12 [174]. There is a need to examine if muscle-derived CXCL-12 in response to exercise impacts on feeding behaviours. Given the role of CXCL-12 in satellite cell activity, there is also a need to examine the expression and secretion of CXCL-12 from muscle in response to weight loss, as this may be a link between muscle loss and weight regain. 


\section{Relevance for Obesity Prevention and Obesity Management}

The aim of this review was to highlight the over-3000 discovered myokines as potential key targets of interest for appetite control and body weight regulation. Efforts have been made to identify myokines that may be potential therapeutic targets for muscle wasting [175]. In the theme of precision medicine, bimagrumab (BYM338; Novartis) was initially developed as a potential therapeutic for myositis. Mechanistically, bimagrumab is a fully human monoclonal antibody that can bind to activin type II receptors. As a result, endogenous ligands such as Activin A, Activin B and GDF-11 are blocked. Of significant interest is the consequence of blocking the action of the negative regulator of muscle size, myostatin. In individuals with insulin resistance, a single dose of bimagrumab increased LM and decreased FM due to blocking of the action of myostatin [176]. In the RESILIENT phase II clinical trial of people living with inclusion body myositis, whilst the safety profile was satisfactory, the primary endpoint, a 6 min walk test, did not change after bimagrumab treatment [177].

Recently, the evidence regarding bimagrumab and body composition changes has been further explored in a Phase 2 clinical trial of people with obesity and type 2 diabetes [178]. Seventy-five individuals were randomised to diet and exercise vs. diet and exercise plus bimagrumab for 48 weeks. Patients met a dietician monthly who prescribed a $500 \mathrm{kcal}$ deficit diet combined with basic instructions with regard to achieving the guidelines for moderate intensity walking. The primary end point was a change in FM measured via dual energy X-ray absorptiometry. Bimagrumab reduced FM by $20.5 \%$ vs. $-0.5 \%$ with placebo, while LM increased by $3.6 \%$ vs. $-0.5 \%$ with placebo. Total weight loss with bimagrumab was $6.5 \%$ with a significant improvement in HBA1c. Given that weight loss with increasing magnitude increases risk of LM loss [32], these findings are unique compared to other anti-obesity medications.

Whilst the mechanism responsible for muscle gain is likely related to inhibition of myostatin, the mechanism for weight loss remains unknown. In animals, bimagrumab appears to have a thermogenic effect on BAT and increased energy expenditure [179]. Given the fact that activin II receptors are present in white adipose tissue, a direct effect on this tissue may explain the weight loss effect. Importantly, the effect of bimagrumab on energy intake and energy expenditure remains to be examined in detail. The potential effect on the brain and thus feeding behaviours and centrally controlled energy expenditure must be elucidated. Previously, myostatin inhibition in patients with lipodystrophy reduced food intake [155].

This breakthrough finding of Heymsfield et al. increases the need to understand how muscle regulates body composition and talks to the brain [178]. As described in this review, several myokines are hypothetically important in driving weight loss and weight loss maintenance in response to exercise. In addition, some myokines may be important in potentially driving weight regain after weight loss, where interventions cause reductions in LM. By understanding organ cross-talk, there is a scope to improve our understanding of obesity as a disease and any disease negatively impacting body composition and body weight. Whilst exercise for most drives health gain independent of weight changes, having the ability to predict who will respond to specific exercise types with favourable body composition changes has the potential to transform the care of patients.

\section{Conclusions}

Obesity as a disease remains a global epidemic. In the absence of large-scale structural changes to the environment which currently promote a higher body weight, this disease will negatively impact on peoples' lived experience. Furthermore, the strain on healthcare and economic resources will not abate. There is a need to understand the biology of this disease to enhance prevention and treatment methods via cost-effective approaches. Given that skeletal muscle appears to play an underappreciated role in appetite control and body weight regulation, efforts should be placed on examining myokines as determinants of outcomes. Expanding our understanding may unlock novel approaches that greatly 
enhance our clinical care. Furthermore, in response to weight loss, factors from muscle that may drive food intake in an attempt to restore muscle to its set point can potentially be exploited pharmacologically. The developments of safe and effective medications to treat muscle-wasting diseases, cachexia and sarcopenia are desperately needed.

Author Contributions: Conceptualization, A.G. and C.W.1.R.; methodology, A.G., A.K. and C.W.1.R.; formal analysis, A.G.; investigation, A.G. and A.K.; writing-original draft preparation, A.G. and A.K.; writing-review and editing, A.G., A.K. and C.W.1.R.; supervision, C.W.1.R.; project administration, A.G.; funding acquisition, A.G. All authors have read and agreed to the published version of the manuscript.

Funding: The research conducted in this publication was funded by the Irish Research Council under the Enterprise Partnership Scheme Fellow, grant number (EPSPD/2021/12).

Conflicts of Interest: The authors declare no conflict of interest.

\section{References}

1. Tremmel, M.; Gerdtham, U.G.; Nilsson, P.M.; Saha, S. Economic Burden of Obesity: A Systematic Literature Review. Int. J. Environ. Res. Public Health 2017, 14, 435. [CrossRef] [PubMed]

2. Rubino, F.; Puhl, R.M.; Cummings, D.E.; Eckel, R.H.; Ryan, D.H.; Mechanick, J.I.; Nadglowski, J.; Ramos Salas, X.; Schauer, P.R.; Twenefour, D.; et al. Joint international consensus statement for ending stigma of obesity. Nat. Med. 2020, 26, 485-497. [CrossRef] [PubMed]

3. Sharma, A.M.; Belanger, A.; Carson, V.; Krah, J.; Langlois, M.F.; Lawlor, D.; Lepage, S.; Liu, A.; Macklin, D.A.; MacKay, N.; et al. Perceptions of barriers to effective obesity management in Canada: Results from the ACTION study. Clin. Obes. 2019, 9, e12329. [CrossRef] [PubMed]

4. Murphy, D. Concepts of Disease and Health. Spring 2021 ed.; Metaphysics Research Lab, Stanford Univeristy: 2021. Available online: https:/ / plato.stanford.edu/entries/health-disease/ (accessed on 4 December 2021).

5. Heymsfield, S.B.; Wadden, T.A. Mechanisms, Pathophysiology, and Management of Obesity. N. Engl. J. Med. 2017, $376,1492$. [CrossRef] [PubMed]

6. le Roux, C.W.; Batterham, R.L.; Aylwin, S.J.; Patterson, M.; Borg, C.M.; Wynne, K.J.; Kent, A.; Vincent, R.P.; Gardiner, J.; Ghatei, M.A.; et al. Attenuated peptide YY release in obese subjects is associated with reduced satiety. Endocrinology 2006, 147, 3-8. [CrossRef]

7. Obradovic, M.; Sudar-Milovanovic, E.; Soskic, S.; Essack, M.; Arya, S.; Stewart, A.J.; Gojobori, T.; Isenovic, E.R. Leptin and Obesity: Role and Clinical Implication. Front. Endocrinol. 2021, 12, 585887. [CrossRef] [PubMed]

8. Jais, A.; Bruning, J.C. Hypothalamic inflammation in obesity and metabolic disease. J. Clin. Investig. 2017, 127, 24-32. [CrossRef]

9. Badman, M.K.; Flier, J.S. The adipocyte as an active participant in energy balance and metabolism. Gastroenterology 2007, 132, 2103-2115. [CrossRef]

10. Leibel, R.L.; Rosenbaum, M.; Hirsch, J. Changes in energy expenditure resulting from altered body weight. N. Engl. J. Med. 1995, 332, 621-628. [CrossRef]

11. Sumithran, P.; Prendergast, L.A.; Delbridge, E.; Purcell, K.; Shulkes, A.; Kriketos, A.; Proietto, J. Long-term persistence of hormonal adaptations to weight loss. N. Engl. J. Med. 2011, 365, 1597-1604. [CrossRef]

12. Rosenbaum, M.; Leibel, R.L. Adaptive thermogenesis in humans. Int. J. Obes. 2010, 34 (Suppl. S1), S47-S55. [CrossRef] [PubMed]

13. Blundell, J.E.; Caudwell, P.; Gibbons, C.; Hopkins, M.; Naslund, E.; King, N.A.; Finlayson, G. Body composition and appetite: Fat-free mass (but not fat mass or BMI) is positively associated with self-determined meal size and daily energy intake in humans. Br. J. Nutr. 2012, 107, 445-449. [CrossRef]

14. Grannell, A.; Al-Najim, W.; Mangan, A.; Kapoor, N.; Martin, W.P.; Murphy, J.C.; Docherty, N.G.; le Roux, C.W.; Davenport, C. Fat free mass is positively associated with hunger and energy intake at extremes of obesity. Appetite 2019, 143, 104444. [CrossRef] [PubMed]

15. Basolo, A.; Votruba, S.B.; Heinitz, S.; Krakoff, J.; Piaggi, P. Deviations in energy sensing predict long-term weight change in overweight Native Americans. Metabolism 2018, 82, 65-71. [CrossRef]

16. Blundell, J.E.; Gibbons, C.; Beaulieu, K.; Casanova, N.; Duarte, C.; Finlayson, G.; Stubbs, R.J.; Hopkins, M. The drive to eat in homo sapiens: Energy expenditure drives energy intake. Physiol. Behav. 2020, 219, 112846. [CrossRef]

17. Watts, A.G.; Kanoski, S.E.; Sanchez-Watts, G.; Langhans, W. The Physiological Control of Eating: Signals, Neurons, and Networks. Physiol. Rev. 2021, 102, 689-813. [CrossRef]

18. Mayer, J.; Roy, P.; Mitra, K.P. Relation between caloric intake, body weight, and physical work: Studies in an industrial male population in West Bengal. Am. J. Clin. Nutr. 1956, 4, 169-175. [CrossRef]

19. Beaulieu, K.; Hopkins, M.; Blundell, J.; Finlayson, G. Does Habitual Physical Activity Increase the Sensitivity of the Appetite Control System? A Systematic Review. Sports Med. 2016, 46, 1897-1919. [CrossRef]

20. Grannell, A.; Fallon, F.; Pournaras, D.; le Roux, C.W. Exploring patient beliefs and perceptions regarding obesity as a disease, obesity causation and treatment. Ir. J. Med. Sci. 2021, 190, 163-168. [CrossRef] 
21. Thorogood, A.; Mottillo, S.; Shimony, A.; Filion, K.B.; Joseph, L.; Genest, J.; Pilote, L.; Poirier, P.; Schiffrin, E.L.; Eisenberg, M.J. Isolated aerobic exercise and weight loss: A systematic review and meta-analysis of randomized controlled trials. Am. J. Med. 2011, 124, 747-755. [CrossRef]

22. Careau, V.; Halsey, L.G.; Pontzer, H.; Ainslie, P.N.; Andersen, L.F.; Anderson, L.J.; Arab, L.; Baddou, I.; Bedu-Addo, K.; Blaak, E.E.; et al. Energy compensation and adiposity in humans. Curr. Biol. 2021, 31, 4659-4666.e2. [CrossRef]

23. Pontzer, H. Constrained Total Energy Expenditure and the Evolutionary Biology of Energy Balance. Exerc. Sport. Sci. Rev. 2015, 43, 110-116. [CrossRef] [PubMed]

24. Gibbons, C.; Blundell, J.E.; Caudwell, P.; Webb, D.L.; Hellstrom, P.M.; Naslund, E.; Finlayson, G. The Role of Episodic Postprandial Peptides in Exercise-Induced Compensatory Eating. J. Clin. Endocrinol. Metab. 2017, 102, 4051-4059. [CrossRef] [PubMed]

25. King, N.A.; Hopkins, M.; Caudwell, P.; Stubbs, R.J.; Blundell, J.E. Individual variability following 12 weeks of supervised exercise: Identification and characterization of compensation for exercise-induced weight loss. Int. J. Obes. 2008, 32, 177-184. [CrossRef] [PubMed]

26. Paixao, C.; Dias, C.M.; Jorge, R.; Carraca, E.V.; Yannakoulia, M.; de Zwaan, M.; Soini, S.; Hill, J.O.; Teixeira, P.J.; Santos, I. Successful weight loss maintenance: A systematic review of weight control registries. Obes. Rev. 2020, 21, e13003. [CrossRef]

27. Le Roux, C.W.; Heneghan, H.M. Bariatric Surgery for Obesity. Med. Clin. N. Am. 2018, 102, 165-182. [CrossRef]

28. Lau, D.C.W.; Erichsen, L.; Francisco, A.M.; Satylganova, A.; le Roux, C.W.; McGowan, B.; Pedersen, S.D.; Pietilainen, K.H.; Rubino, D.; Batterham, R.L. Once-weekly cagrilintide for weight management in people with overweight and obesity: A multicentre, randomised, double-blind, placebo-controlled and active-controlled, dose-finding phase 2 trial. Lancet 2021, 398, 2160-2172. [CrossRef]

29. Fothergill, E.; Guo, J.; Howard, L.; Kerns, J.C.; Knuth, N.D.; Brychta, R.; Chen, K.Y.; Skarulis, M.C.; Walter, M.; Walter, P.J.; et al. Persistent metabolic adaptation 6 years after "The Biggest Loser" competition. Obesity 2016, 24, 1612-1619. [CrossRef]

30. Hall, K.D. Energy compensation and metabolic adaptation: "The Biggest Loser" study reinterpreted. Obesity 2022, $30,11-13$. [CrossRef]

31. Forbes, G.B. Lean body mass-body fat interrelationships in humans. Nutr. Rev. 1987, 45, 225-231. [CrossRef]

32. Chaston, T.B.; Dixon, J.B.; O'Brien, P.E. Changes in fat-free mass during significant weight loss: A systematic review. Int. J. Obes. 2007, 31, 743-750. [CrossRef]

33. Bosy-Westphal, A.; Kossel, E.; Goele, K.; Later, W.; Hitze, B.; Settler, U.; Heller, M.; Gluer, C.C.; Heymsfield, S.B.; Muller, M.J Contribution of individual organ mass loss to weight loss-associated decline in resting energy expenditure. Am. J. Clin. Nutr. 2009, 90, 993-1001. [CrossRef] [PubMed]

34. University of Minnesota, Laboratory of Physiological Hygiene; Keys, A.B. The Biology of Human Starvation; University of Minnesota Press: Minneapolis, MN, USA, 1950; Volume 2, 1385p.

35. Dulloo, A.G. Physiology of weight regain: Lessons from the classic Minnesota Starvation Experiment on human body composition regulation. Obes. Rev. 2021, 22 (Suppl. S2), e13189. [CrossRef] [PubMed]

36. Dulloo, A.G.; Jacquet, J.; Girardier, L. Poststarvation hyperphagia and body fat overshooting in humans: A role for feedback signals from lean and fat tissues. Am. J. Clin. Nutr. 1997, 65, 717-723. [CrossRef] [PubMed]

37. Vink, R.G.; Roumans, N.J.; Arkenbosch, L.A.; Mariman, E.C.; van Baak, M.A. The effect of rate of weight loss on long-term weight regain in adults with overweight and obesity. Obesity 2016, 24, 321-327. [CrossRef] [PubMed]

38. Turicchi, J.; O'Driscoll, R.; Finlayson, G.; Beaulieu, K.; Deighton, K.; Stubbs, R.J. Associations between the rate, amount, and composition of weight loss as predictors of spontaneous weight regain in adults achieving clinically significant weight loss: A systematic review and meta-regression. Obes. Rev. 2019, 20, 935-946. [CrossRef]

39. Turicchi, J.; O’Driscoll, R.; Finlayson, G.; Duarte, C.; Hopkins, M.; Martins, N.; Michalowska, J.; Larsen, T.M.; van Baak, M.A.; Astrup, A.; et al. Associations between the proportion of fat-free mass loss during weight loss, changes in appetite, and subsequent weight change: Results from a randomized 2-stage dietary intervention trial. Am. J. Clin. Nutr. 2020, 111, 536-544. [CrossRef]

40. Flack, K.D.; Hays, H.M.; Moreland, J. The consequences of exercise-induced weight loss on food reinforcement. A randomized controlled trial. PLoS ONE 2020, 15, e0234692. [CrossRef]

41. Hao, Z.; Mumphrey, M.B.; Townsend, R.L.; Morrison, C.D.; Munzberg, H.; Ye, J.; Berthoud, H.R. Reprogramming of defended body weight after Roux-En-Y gastric bypass surgery in diet-induced obese mice. Obesity 2016, 24, 654-660. [CrossRef]

42. Hall, K.D. Body fat and fat-free mass inter-relationships: Forbes's theory revisited. Br. J. Nutr. 2007, 97, 1059-1063. [CrossRef]

43. Severinsen, M.C.K.; Pedersen, B.K. Muscle-Organ Crosstalk: The Emerging Roles of Myokines. Endocr. Rev. 2020, 41, 594-609. [CrossRef] [PubMed]

44. Pedersen, B.K. Physical activity and muscle-brain crosstalk. Nat. Rev. Endocrinol. 2019, 15, 383-392. [CrossRef]

45. Ruderman, N.B.; Keller, C.; Richard, A.M.; Saha, A.K.; Luo, Z.; Xiang, X.; Giralt, M.; Ritov, V.B.; Menshikova, E.V.; Kelley, D.E.; et al. Interleukin-6 regulation of AMP-activated protein kinase. Potential role in the systemic response to exercise and prevention of the metabolic syndrome. Diabetes 2006, 55 (Suppl. S2), S48-S54. [CrossRef]

46. Ellingsgaard, H.; Hauselmann, I.; Schuler, B.; Habib, A.M.; Baggio, L.L.; Meier, D.T.; Eppler, E.; Bouzakri, K.; Wueest, S.; Muller, Y.D.; et al. Interleukin-6 enhances insulin secretion by increasing glucagon-like peptide-1 secretion from L cells and alpha cells. Nat. Med. 2011, 17, 1481-1489. [CrossRef] [PubMed]

47. Shizuya, K.; Komori, T.; Fujiwara, R.; Miyahara, S.; Ohmori, M.; Nomura, J. The influence of restraint stress on the expression of mRNAs for IL-6 and the IL-6 receptor in the hypothalamus and midbrain of the rat. Life Sci. 1997, 61, 135-140. [CrossRef] 
48. Patsalos, O.; Dalton, B.; Himmerich, H. Effects of IL-6 Signaling Pathway Inhibition on Weight and BMI: A Systematic Review and Meta-Analysis. Int. J. Mol. Sci. 2020, 21, 6290. [CrossRef] [PubMed]

49. Chida, D.; Osaka, T.; Hashimoto, O.; Iwakura, Y. Combined interleukin-6 and interleukin-1 deficiency causes obesity in young mice. Diabetes 2006, 55, 971-977. [CrossRef]

50. Wallenius, V.; Wallenius, K.; Ahren, B.; Rudling, M.; Carlsten, H.; Dickson, S.L.; Ohlsson, C.; Jansson, J.O. Interleukin-6-deficient mice develop mature-onset obesity. Nat. Med. 2002, 8, 75-79. [CrossRef]

51. Hidalgo, J.; Florit, S.; Giralt, M.; Ferrer, B.; Keller, C.; Pilegaard, H. Transgenic mice with astrocyte-targeted production of interleukin- 6 are resistant to high-fat diet-induced increases in body weight and body fat. Brain Behav. Immun. 2010, 24, 119-126. [CrossRef]

52. Bobbo, V.C.; Engel, D.F.; Jara, C.P.; Mendes, N.F.; Haddad-Tovolli, R.; Prado, T.P.; Sidarta-Oliveira, D.; Morari, J.; Velloso, L.A.; Araujo, E.P. Interleukin- 6 actions in the hypothalamus protects against obesity and is involved in the regulation of neurogenesis. J. Neuroinflamm. 2021, 18, 192. [CrossRef] [PubMed]

53. Mishra, D.; Richard, J.E.; Maric, I.; Porteiro, B.; Haring, M.; Kooijman, S.; Musovic, S.; Eerola, K.; Lopez-Ferreras, L.; Peris, E.; et al. Parabrachial Interleukin-6 Reduces Body Weight and Food Intake and Increases Thermogenesis to Regulate Energy Metabolism. Cell Rep. 2019, 26, 3011-3026.e5. [CrossRef] [PubMed]

54. Hunschede, S.; Kubant, R.; Akilen, R.; Thomas, S.; Anderson, G.H. Decreased Appetite after High-Intensity Exercise Correlates with Increased Plasma Interleukin-6 in Normal-Weight and Overweight/Obese Boys. Curr. Dev. Nutr. 2017, 1, e000398. [CrossRef] [PubMed]

55. Broom, D.R.; Batterham, R.L.; King, J.A.; Stensel, D.J. Influence of resistance and aerobic exercise on hunger, circulating levels of acylated ghrelin, and peptide YY in healthy males. Am. J. Physiol Regul. Integr. Comp. Physiol. 2009, 296, R29-R35. [CrossRef]

56. Hazell, T.J.; Islam, H.; Hallworth, J.R.; Copeland, J.L. Total PYY and GLP-1 responses to submaximal continuous and supramaximal sprint interval cycling in men. Appetite 2017, 108, 238-244. [CrossRef]

57. Islam, H.; Townsend, L.K.; Hazell, T.J. Modified sprint interval training protocols. Part I. Physiological responses. Appl Physiol Nutr. Metab. 2017, 42, 339-346. [CrossRef]

58. Gheller, B.J.; Blum, J.E.; Merritt, E.K.; Cummings, B.P.; Thalacker-Mercer, A.E. Peptide YY (PYY) Is Expressed in Human Skeletal Muscle Tissue and Expanding Human Muscle Progenitor Cells. Front. Physiol. 2019, 10, 188. [CrossRef] [PubMed]

59. Thalacker-Mercer, A.; Stec, M.; Cui, X.; Cross, J.; Windham, S.; Bamman, M. Cluster analysis reveals differential transcript profiles associated with resistance training-induced human skeletal muscle hypertrophy. Physiol. Genom. 2013, 45, 499-507. [CrossRef] [PubMed]

60. Le Roux, C.W.; Aylwin, S.J.; Batterham, R.L.; Borg, C.M.; Coyle, F.; Prasad, V.; Shurey, S.; Ghatei, M.A.; Patel, A.G.; Bloom, S.R. Gut hormone profiles following bariatric surgery favor an anorectic state, facilitate weight loss, and improve metabolic parameters Ann. Surg. 2006, 243, 108-114. [CrossRef]

61. Batterham, R.L.; Cowley, M.A.; Small, C.J.; Herzog, H.; Cohen, M.A.; Dakin, C.L.; Wren, A.M.; Brynes, A.E.; Low, M.J.; Ghatei, M.A.; et al. Gut hormone PYY(3-36) physiologically inhibits food intake. Nature 2002, 418, 650-654. [CrossRef]

62. Yan, Q.; Rosenfeld, R.D.; Matheson, C.R.; Hawkins, N.; Lopez, O.T.; Bennett, L.; Welcher, A.A. Expression of brain-derived neurotrophic factor protein in the adult rat central nervous system. Neuroscience 1997, 78, 431-448. [CrossRef]

63. Cordeira, J.W.; Frank, L.; Sena-Esteves, M.; Pothos, E.N.; Rios, M. Brain-derived neurotrophic factor regulates hedonic feeding by acting on the mesolimbic dopamine system. J. Neurosci 2010, 30, 2533-2541. [CrossRef]

64. Pelleymounter, M.A.; Cullen, M.J.; Wellman, C.L. Characteristics of BDNF-induced weight loss. Exp. Neurol. 1995, 131, 229-238. [CrossRef]

65. Bumb, J.M.; Bach, P.; Grosshans, M.; Wagner, X.; Koopmann, A.; Vollstadt-Klein, S.; Schuster, R.; Wiedemann, K.; Kiefer, F. BDNF influences neural cue-reactivity to food stimuli and food craving in obesity. Eur. Arch. Psychiatry Clin. Neurosci. 2021, 271, 963-974. [CrossRef]

66. Fox, E.A.; Biddinger, J.E.; Jones, K.R.; McAdams, J.; Worman, A. Mechanism of hyperphagia contributing to obesity in brainderived neurotrophic factor knockout mice. Neuroscience 2013, 229, 176-199. [CrossRef] [PubMed]

67. Yeo, G.S.; Connie Hung, C.C.; Rochford, J.; Keogh, J.; Gray, J.; Sivaramakrishnan, S.; O'Rahilly, S.; Farooqi, I.S. A de novo mutation affecting human TrkB associated with severe obesity and developmental delay. Nat. Neurosci. 2004, 7, 1187-1189. [CrossRef] [PubMed]

68. Waterhouse, E.G.; Xu, B. The skinny on brain-derived neurotrophic factor: Evidence from animal models to GWAS. J. Mol. Med. 2013, 91, 1241-1247. [CrossRef]

69. Pedersen, B.K.; Pedersen, M.; Krabbe, K.S.; Bruunsgaard, H.; Matthews, V.B.; Febbraio, M.A. Role of exercise-induced brainderived neurotrophic factor production in the regulation of energy homeostasis in mammals. Exp. Physiol. 2009, 94, 1153-1160. [CrossRef]

70. Yang, X.; Brobst, D.; Chan, W.S.; Tse, M.C.L.; Herlea-Pana, O.; Ahuja, P.; Bi, X.; Zaw, A.M.; Kwong, Z.S.W.; Jia, W.H.; et al. Muscle-generated BDNF is a sexually dimorphic myokine that controls metabolic flexibility. Sci. Signal. 2019, 12. [CrossRef]

71. Scisciola, L.; Fontanella, R.A.; Surina; Cataldo, V.; Paolisso, G.; Barbieri, M. Sarcopenia and Cognitive Function: Role of Myokines in Muscle Brain Cross-Talk. Life 2021, 11, 173. [CrossRef] 
72. Sandrini, L.; di Minno, A.; Amadio, P.; Ieraci, A.; Tremoli, E.; Barbieri, S.S. Association between Obesity and Circulating BrainDerived Neurotrophic Factor (BDNF) Levels: Systematic Review of Literature and Meta-Analysis. Int. J. Mol. Sci. 2018, 19 , 2281. [CrossRef]

73. Yen, H.H.; Hsieh, S.T.; Chen, C.L.; Yang, W.S.; Lee, P.C.; Lin, M.T.; Chen, C.N.; Yang, P.J. Circulating Diabetic Candidate Neurotrophic Factors, Brain-Derived Neurotrophic Factor and Fibroblast Growth Factor 21, in Sleeve Gastrectomy. Sci. Rep. 2020, 10, 5341. [CrossRef] [PubMed]

74. Schmolesky, M.T.; Webb, D.L.; Hansen, R.A. The effects of aerobic exercise intensity and duration on levels of brain-derived neurotrophic factor in healthy men. J. Sports. Sci. Med. 2013, 12, 502-511. [PubMed]

75. Glud, M.; Christiansen, T.; Larsen, L.H.; Richelsen, B.; Bruun, J.M. Changes in Circulating BDNF in relation to Sex, Diet, and Exercise: A 12-Week Randomized Controlled Study in Overweight and Obese Participants. J. Obes. 2019, 2019, 4537274. [CrossRef]

76. Maury, E.; Ehala-Aleksejev, K.; Guiot, Y.; Detry, R.; Vandenhooft, A.; Brichard, S.M. Adipokines oversecreted by omental adipose tissue in human obesity. Am. J. Physiol. Endocrinol. Metab. 2007, 293, E656-E665. [CrossRef] [PubMed]

77. Macia, L.; Viltart, O.; Delacre, M.; Sachot, C.; Heliot, L.; di Santo, J.P.; Wolowczuk, I. Interleukin-7, a new cytokine targeting the mouse hypothalamic arcuate nucleus: Role in body weight and food intake regulation. PLoS ONE 2010, 5, e9953. [CrossRef] [PubMed]

78. Lucas, S.; Taront, S.; Magnan, C.; Fauconnier, L.; Delacre, M.; Macia, L.; Delanoye, A.; Verwaerde, C.; Spriet, C.; Saule, P.; et al. Interleukin-7 regulates adipose tissue mass and insulin sensitivity in high-fat diet-fed mice through lymphocyte-dependent and independent mechanisms. PLOS ONE 2012, 7, e40351. [CrossRef]

79. Germain, N.; Viltart, O.; Loyens, A.; Bruchet, C.; Nadin, K.; Wolowczuk, I.; Estour, B.; Galusca, B. Interleukin-7 Plasma Levels in Human Differentiate Anorexia Nervosa, Constitutional Thinness and Healthy Obesity. PLoS ONE 2016, 11, e0161890. [CrossRef] [PubMed]

80. Germain, N.; Galusca, B.; le Roux, C.W.; Bossu, C.; Ghatei, M.A.; Lang, F.; Bloom, S.R.; Estour, B. Constitutional thinness and lean anorexia nervosa display opposite concentrations of peptide YY, glucagon-like peptide 1, ghrelin, and leptin. Am. J. Clin. Nutr. 2007, 85, 967-971. [CrossRef]

81. Haugen, F.; Norheim, F.; Lian, H.; Wensaas, A.J.; Dueland, S.; Berg, O.; Funderud, A.; Skalhegg, B.S.; Raastad, T.; Drevon, C.A. IL-7 is expressed and secreted by human skeletal muscle cells. Am. J. Physiol. Cell Physiol. 2010, 298, C807-C816. [CrossRef]

82. Andersson, H.; Bohn, S.K.; Raastad, T.; Paulsen, G.; Blomhoff, R.; Kadi, F. Differences in the inflammatory plasma cytokine response following two elite female soccer games separated by a 72-h recovery. Scand. J. Med. Sci. Sports 2010, $20,740-747$. [CrossRef]

83. Fioravante, M.; Bombassaro, B.; Ramalho, A.F.; Dragano, N.R.; Morari, J.; Solon, C.; Tobar, N.; Ramos, C.D.; Velloso, L.A. Inhibition of hypothalamic leukemia inhibitory factor exacerbates diet-induced obesity phenotype. J. Neuroinflamm. 2017, 14, 178. [CrossRef] [PubMed]

84. Licursi, M.; Alberto, C.O.; Dias, A.; Hirasawa, K.; Hirasawa, M. High-fat diet-induced downregulation of anorexic leukemia inhibitory factor in the brain stem. Obesity 2016, 24, 2361-2367. [CrossRef] [PubMed]

85. Grossberg, A.J.; Scarlett, J.M.; Zhu, X.; Bowe, D.D.; Batra, A.K.; Braun, T.P.; Marks, D.L. Arcuate nucleus proopiomelanocortin neurons mediate the acute anorectic actions of leukemia inhibitory factor via gp130. Endocrinology 2010, 151, 606-616. [CrossRef] [PubMed]

86. Beretta, E.; Dhillon, H.; Kalra, P.S.; Kalra, S.P. Central LIF gene therapy suppresses food intake, body weight, serum leptin and insulin for extended periods. Peptides 2002, 23, 975-984. [CrossRef]

87. Jansson, J.O.; Moverare-Skrtic, S.; Berndtsson, A.; Wernstedt, I.; Carlsten, H.; Ohlsson, C. Leukemia inhibitory factor reduces body fat mass in ovariectomized mice. Eur. J. Endocrinol. 2006, 154, 349-354. [CrossRef] [PubMed]

88. So, B.; Kim, H.J.; Kim, J.; Song, W. Exercise-induced myokines in health and metabolic diseases. Integr. Med. Res. 2014, 3, 172-179. [CrossRef]

89. Broholm, C.; Laye, M.J.; Brandt, C.; Vadalasetty, R.; Pilegaard, H.; Pedersen, B.K.; Scheele, C. LIF is a contraction-induced myokine stimulating human myocyte proliferation. J. Appl. Physiol 2011, 111, 251-259. [CrossRef]

90. Broholm, C.; Mortensen, O.H.; Nielsen, S.; Akerstrom, T.; Zankari, A.; Dahl, B.; Pedersen, B.K. Exercise induces expression of leukaemia inhibitory factor in human skeletal muscle. J. Physiol. 2008, 586, 2195-2201. [CrossRef]

91. Kapilevich, L.V.; Zakharova, A.N.; Kabachkova, A.V.; Kironenko, T.A.; Orlov, S.N. Dynamic and Static Exercises Differentially Affect Plasma Cytokine Content in Elite Endurance- and Strength-Trained Athletes and Untrained Volunteers. Front. Physiol. 2017, 8, 35. [CrossRef]

92. Pan, W.; Kastin, A.J.; Brennan, J.M. Saturable entry of leukemia inhibitory factor from blood to the central nervous system. J Neuroimmunol 2000, 106, 172-180. [CrossRef]

93. Grootaert, C.; van de Wiele, T.; Verstraete, W.; Bracke, M.; Vanhoecke, B. Angiopoietin-like protein 4: Health effects, modulating agents and structure-function relationships. Expert Rev. Proteom. 2012, 9, 181-199. [CrossRef] [PubMed]

94. Aryal, B.; Singh, A.K.; Zhang, X.; Varela, L.; Rotllan, N.; Goedeke, L.; Chaube, B.; Camporez, J.P.; Vatner, D.F.; Horvath, T.L.; et al. Absence of ANGPTL4 in adipose tissue improves glucose tolerance and attenuates atherogenesis. JCI Insight 2018, 3. [CrossRef] [PubMed]

95. Kim, H.K.; Youn, B.S.; Shin, M.S.; Namkoong, C.; Park, K.H.; Baik, J.H.; Kim, J.B.; Park, J.Y.; Lee, K.U.; Kim, Y.B.; et al. Hypothalamic Angptl4/Fiaf is a novel regulator of food intake and body weight. Diabetes 2010, 59, 2772-2780. [CrossRef] 
96. Kersten, S.; Lichtenstein, L.; Steenbergen, E.; Mudde, K.; Hendriks, H.F.; Hesselink, M.K.; Schrauwen, P.; Muller, M. Caloric restriction and exercise increase plasma ANGPTL4 levels in humans via elevated free fatty acids. Arter. Thromb. Vasc. Biol. 2009, 29, 969-974. [CrossRef]

97. Norheim, F.; Hjorth, M.; Langleite, T.M.; Lee, S.; Holen, T.; Bindesboll, C.; Stadheim, H.K.; Gulseth, H.L.; Birkeland, K.I.; Kielland, A.; et al. Regulation of angiopoietin-like protein 4 production during and after exercise. Physiol. Rep. 2014, 2, e12109. [CrossRef]

98. Van der Kolk, B.W.; Goossens, G.H.; Jocken, J.W.; Kersten, S.; Blaak, E.E. Angiopoietin-Like Protein 4 and Postprandial Skeletal Muscle Lipid Metabolism in Overweight and Obese Prediabetics. J. Clin. Endocrinol. Metab. 2016, 101, 2332-2339. [CrossRef]

99. Van der Kolk, B.W.; Vink, R.G.; Jocken, J.W.E.; Roumans, N.J.T.; Goossens, G.H.; Mariman, E.C.M.; van Baak, M.A.; Blaak, E.E. Effect of diet-induced weight loss on angiopoietin-like protein 4 and adipose tissue lipid metabolism in overweight and obese humans. Physiol. Rep. 2018, 6, e13735. [CrossRef]

100. Jensen, G.S.; Leon-Palmer, N.E.; Townsend, K.L. Bone morphogenetic proteins (BMPs) in the central regulation of energy balance and adult neural plasticity. Metabolism 2021, 123, 154837. [CrossRef] [PubMed]

101. Winbanks, C.E.; Chen, J.L.; Qian, H.; Liu, Y.; Bernardo, B.C.; Beyer, C.; Watt, K.I.; Thomson, R.E.; Connor, T.; Turner, B.J.; et al. The bone morphogenetic protein axis is a positive regulator of skeletal muscle mass. J. Cell Biol. 2013, 203, 345-357. [CrossRef]

102. Townsend, K.L.; Suzuki, R.; Huang, T.L.; Jing, E.; Schulz, T.J.; Lee, K.; Taniguchi, C.M.; Espinoza, D.O.; McDougall, L.E.; Zhang, H.; et al. Bone morphogenetic protein 7 (BMP7) reverses obesity and regulates appetite through a central mTOR pathway. FASEB J. 2012, 26, 2187-2196. [CrossRef]

103. Townsend, K.L.; Madden, C.J.; Blaszkiewicz, M.; McDougall, L.; Tupone, D.; Lynes, M.D.; Mishina, Y.; Yu, P.; Morrison, S.F.; Tseng, Y.H. Reestablishment of Energy Balance in a Male Mouse Model With POMC Neuron Deletion of BMPR1A. Endocrinology 2017, 158, 4233-4245. [CrossRef] [PubMed]

104. Bottcher, Y.; Unbehauen, H.; Kloting, N.; Ruschke, K.; Korner, A.; Schleinitz, D.; Tonjes, A.; Enigk, B.; Wolf, S.; Dietrich, K.; et al. Adipose tissue expression and genetic variants of the bone morphogenetic protein receptor 1A gene (BMPR1A) are associated with human obesity. Diabetes 2009, 58, 2119-2128. [CrossRef] [PubMed]

105. Schleinitz, D.; Kloting, N.; Bottcher, Y.; Wolf, S.; Dietrich, K.; Tonjes, A.; Breitfeld, J.; Enigk, B.; Halbritter, J.; Korner, A.; et al. Genetic and evolutionary analyses of the human bone morphogenetic protein receptor 2 (BMPR2) in the pathophysiology of obesity. PLoS ONE 2011, 6, e16155. [CrossRef] [PubMed]

106. Kim, J.S.; Lee, Y.H.; Yi, H.K. Gradual downhill running improves age-related skeletal muscle and bone weakness: Implication of autophagy and bone morphogenetic proteins. Exp. Physiol. 2016, 101, 1528-1540. [CrossRef] [PubMed]

107. Rocha-Rodrigues, S.; Rodriguez, A.; Gouveia, A.M.; Goncalves, I.O.; Becerril, S.; Ramirez, B.; Beleza, J.; Fruhbeck, G.; Ascensao, A.; Magalhaes, J. Effects of physical exercise on myokines expression and brown adipose-like phenotype modulation in rats fed a high-fat diet. Life Sci. 2016, 165, 100-108. [CrossRef] [PubMed]

108. Patel, S.; Alvarez-Guaita, A.; Melvin, A.; Rimmington, D.; Dattilo, A.; Miedzybrodzka, E.L.; Cimino, I.; Maurin, A.C.; Roberts, G.P.; Meek, C.L.; et al. GDF15 Provides an Endocrine Signal of Nutritional Stress in Mice and Humans. Cell Metab. 2019, 29, 707-718.e8. [CrossRef] [PubMed]

109. Wang, D.; Day, E.A.; Townsend, L.K.; Djordjevic, D.; Jorgensen, S.B.; Steinberg, G.R. GDF15: Emerging biology and therapeutic applications for obesity and cardiometabolic disease. Nat. Rev. Endocrinol. 2021, 17, 592-607. [CrossRef] [PubMed]

110. Worth, A.A.; Shoop, R.; Tye, K.; Feetham, C.H.; D'Agostino, G.; Dodd, G.T.; Reimann, F.; Gribble, F.M.; Beebe, E.C.; Dunbar, J.D.; et al. The cytokine GDF15 signals through a population of brainstem cholecystokinin neurons to mediate anorectic signalling. Elife 2020, 9, e55164. [CrossRef]

111. Tran, T.; Yang, J.; Gardner, J.; Xiong, Y. GDF15 deficiency promotes high fat diet-induced obesity in mice. PLoS ONE 2018, 13, e0201584. [CrossRef]

112. Boström, P.; Wu, J.; Jedrychowski, M.P.; Korde, A.; Ye, L.; Lo, J.C.; Rasbach, K.A.; Boström, E.A.; Choi, J.H.; Long, J.Z.; et al. A PGC1- $\alpha$-dependent myokine that drives brown-fat-like development of white fat and thermogenesis. Nature 2012, 481, 463-468. [CrossRef]

113. Niranjan, S.B.; Belwalkar, S.V.; Tambe, S.; Venkataraman, K.; Mookhtiar, K.A. Recombinant irisin induces weight loss in high fat DIO mice through increase in energy consumption and thermogenesis. Biochem. Biophys. Res. Commun. 2019, 519, 422-429. [CrossRef] [PubMed]

114. Kim, H.J.; Lee, H.J.; So, B.; Son, J.S.; Yoon, D.; Song, W. Effect of aerobic training and resistance training on circulating irisin level and their association with change of body composition in overweight/obese adults: A pilot study. Physiol. Res. 2016, 65, 271-279. [CrossRef] [PubMed]

115. Timmons, J.A.; Baar, K.; Davidsen, P.K.; Atherton, P.J. Is irisin a human exercise gene? Nature 2012, 488, E9-E10, discussion E10-1. [CrossRef] [PubMed]

116. Norheim, F.; Langleite, T.M.; Hjorth, M.; Holen, T.; Kielland, A.; Stadheim, H.K.; Gulseth, H.L.; Birkeland, K.I.; Jensen, J.; Drevon, C.A. The effects of acute and chronic exercise on PGC- $1 \alpha$, irisin and browning of subcutaneous adipose tissue in humans. FEBS $J$. 2014, 281, 739-749. [CrossRef]

117. Blizzard LeBlanc, D.R.; Rioux, B.V.; Pelech, C.; Moffatt, T.L.; Kimber, D.E.; Duhamel, T.A.; Dolinsky, V.W.; McGavock, J.M.; Sénéchal, M. Exercise-induced irisin release as a determinant of the metabolic response to exercise training in obese youth: The EXIT trial. Physiol. Rep. 2017, 5, e13539. [CrossRef] 
118. Ferrante, C.; Orlando, G.; Recinella, L.; Leone, S.; Chiavaroli, A.; Di Nisio, C.; Shohreh, R.; Manippa, F.; Ricciuti, A.; Vacca, M.; et al. Central inhibitory effects on feeding induced by the adipo-myokine irisin. Eur. J. Pharm. 2016, 791, 389-394. [CrossRef]

119. Demirpence, M.; Yilmaz, H.; Colak, A.; Yalcin, H.; Toprak, B.; Turkon, H.; Ugurlu, L.; Aydin, C. The effect of sleeve gastrectomy on serum irisin levels in patients with morbid obesity. Endokrynol. Pol. 2016, 67, 481-486. [CrossRef]

120. Pardo, M.; Crujeiras, A.B.; Amil, M.; Aguera, Z.; Jiménez-Murcia, S.; Baños, R.; Botella, C.; de la Torre, R.; Estivill, X.; Fagundo, A.B.; et al. Association of irisin with fat mass, resting energy expenditure, and daily activity in conditions of extreme body mass index. Int. J. Endocrinol. 2014, 2014, 857270. [CrossRef]

121. Glück, M.; Glück, J.; Wiewióra, M.; Rogala, B.; Piecuch, J. Serum Irisin, Adropin, and Preptin in Obese Patients 6 Months after Bariatric Surgery. Obes. Surg. 2019, 29, 3334-3341. [CrossRef]

122. Perera, P.Y.; Lichy, J.H.; Waldmann, T.A.; Perera, L.P. The role of interleukin-15 in inflammation and immune responses to infection: Implications for its therapeutic use. Microbes Infect. 2012, 14, 247-261. [CrossRef]

123. Nadeau, L.; Aguer, C. Interleukin-15 as a myokine: Mechanistic insight into its effect on skeletal muscle metabolism. Appl. Physiol. Nutr. Metab. 2019, 44, 229-238. [CrossRef]

124. Quinn, L.S.; Anderson, B.G. Interleukin-15, IL-15 Receptor-Alpha, and Obesity: Concordance of Laboratory Animal and Human Genetic Studies. J. Obes. 2011, 2011, 456347. [CrossRef]

125. O'Leary, M.F.; Wallace, G.R.; Bennett, A.J.; Tsintzas, K.; Jones, S.W. IL-15 promotes human myogenesis and mitigates the detrimental effects of TNF $\alpha$ on myotube development. Sci. Rep. 2017, 7, 12997. [CrossRef]

126. Busquets, S.; Figueras, M.T.; Meijsing, S.; Carbó, N.; Quinn, L.S.; Almendro, V.; Argilés, J.M.; López-Soriano, F.J. Interleukin-15 decreases proteolysis in skeletal muscle: A direct effect. Int. J. Mol. Med. 2005, 16, 471-476. [CrossRef]

127. Barra, N.G.; Chew, M.V.; Reid, S.; Ashkar, A.A. Interleukin-15 treatment induces weight loss independent of lymphocytes. PLoS ONE 2012, 7, e39553.

128. Barra, N.G.; Reid, S.; MacKenzie, R.; Werstuck, G.; Trigatti, B.L.; Richards, C.; Holloway, A.C.; Ashkar, A.A. Interleukin-15 contributes to the regulation of murine adipose tissue and human adipocytes. Obesity 2010, 18, 1601-1607. [CrossRef]

129. Nielsen, A.R.; Hojman, P.; Erikstrup, C.; Fischer, C.P.; Plomgaard, P.; Mounier, R.; Mortensen, O.H.; Broholm, C.; Taudorf, S.; Krogh-Madsen, R.; et al. Association between interleukin-15 and obesity: Interleukin-15 as a potential regulator of fat mass. $J$ Clin. Endocrinol. Metab. 2008, 93, 4486-4493. [CrossRef] [PubMed]

130. Christiansen, T.; Paulsen, S.K.; Bruun, J.M.; Pedersen, S.B.; Richelsen, B. Exercise training versus diet-induced weight-loss on metabolic risk factors and inflammatory markers in obese subjects: A 12-week randomized intervention study. Am. J. Physiol. Endocrinol. Metab. 2010, 298, E824-E831. [CrossRef] [PubMed]

131. Carbó, N.; López-Soriano, J.; Costelli, P.; Alvarez, B.; Busquets, S.; Baccino, F.M.; Quinn, L.S.; López-Soriano, F.J.; Argilés, J.M. Interleukin-15 mediates reciprocal regulation of adipose and muscle mass: A potential role in body weight control. Biochim. Biophys. Acta 2001, 1526, 17-24. [CrossRef]

132. Quinn, L.S.; Strait-Bodey, L.; Anderson, B.G.; Argilés, J.M.; Havel, P.J. Interleukin-15 stimulates adiponectin secretion by 3T3-L1 adipocytes: Evidence for a skeletal muscle-to-fat signaling pathway. Cell Biol. Int. 2005, 29, 449-457. [CrossRef]

133. Almendro, V.; Busquets, S.; Ametller, E.; Carbo, N.; Figueras, M.; Fuster, G.; Argiles, J.M.; Lopez-Soriano, F.J. Effects of interleukin-15 on lipid oxidation: Disposal of an oral [(14)C]-triolein load. Biochim. Biophys. Acta 2006, 1761, 37-42. [CrossRef]

134. Almendro, V.; Fuster, G.; Busquets, S.; Ametller, E.; Figueras, M.; Argilés, J.M.; López-Soriano, F.J. Effects of IL-15 on rat brown adipose tissue: Uncoupling proteins and PPARs. Obesity 2008, 16, 285-289. [CrossRef]

135. Ficek, K.; Cięszczyk, P.; Leźnicka, K.; Kaczmarczyk, M.; Leońska-Duniec, A. Novel Associations between Interleukin-15 Polymorphisms and Post-training Changes of Body Composition Parameters in Young Nonobese Women. Front. Physiol. 2019, 10, 876. [CrossRef] [PubMed]

136. Seldin, M.M.; Peterson, J.M.; Byerly, M.S.; Wei, Z.; Wong, G.W. Myonectin (CTRP15), a novel myokine that links skeletal muscle to systemic lipid homeostasis. J. Biol. Chem. 2012, 287, 11968-11980. [CrossRef]

137. Li, K.; Liao, X.; Wang, K.; Mi, Q.; Zhang, T.; Jia, Y.; Xu, X.; Luo, X.; Zhang, C.; Liu, H.; et al. Myonectin Predicts the Development of Type 2 Diabetes. J. Clin. Endocrinol. Metab. 2018, 103, 139-147. [CrossRef] [PubMed]

138. Pourranjbar, M.; Arabnejad, N.; Naderipour, K.; Rafie, F. Effects of Aerobic Exercises on Serum Levels of Myonectin and Insulin Resistance in Obese and Overweight Women. J. Med. Life 2018, 11, 381-386.

139. Li, L.; Wang, Q.; Qin, C. Serum myonectin is increased after laparoscopic sleeve gastrectomy. Ann. Clin. Biochem. 2020, 57, 360-364. [CrossRef]

140. Wang, H. Skeletal muscle secreted myonectin maintains systemic metabolic homeostasis. FASEB J. 2018.

141. Kubota, N.; Yano, W.; Kubota, T.; Yamauchi, T.; Itoh, S.; Kumagai, H.; Kozono, H.; Takamoto, I.; Okamoto, S.; Shiuchi, T.; et al. Adiponectin stimulates AMP-activated protein kinase in the hypothalamus and increases food intake. Cell Metab. 2007, 6, 55-68. [CrossRef]

142. Hoffmann, K.; Nagel, A.J.; Tanabe, K.; Fuchs, J.; Dehlke, K.; Ghamarnejad, O.; Lemekhova, A.; Mehrabi, A. Markers of liver regeneration-the role of growth factors and cytokines: A systematic review. BMC Surg. 2020, 20, 31. [CrossRef]

143. Lam, B.Y.H.; Williamson, A.; Finer, S.; Day, F.R.; Tadross, J.A.; Goncalves Soares, A.; Wade, K.; Sweeney, P.; Bedenbaugh, M.N.; Porter, D.T.; et al. MC3R links nutritional state to childhood growth and the timing of puberty. Nature 2021, 599, 436-441. [CrossRef] 
144. Perrini, S.; Laviola, L.; Carreira, M.C.; Cignarelli, A.; Natalicchio, A.; Giorgino, F. The GH/IGF1 axis and signaling pathways in the muscle and bone: Mechanisms underlying age-related skeletal muscle wasting and osteoporosis. J. Endocrinol. 2010, 205, 201-210. [CrossRef] [PubMed]

145. Hong, H.; Cui, Z.Z.; Zhu, L.; Fu, S.P.; Rossi, M.; Cui, Y.H.; Zhu, B.M. Central IGF1 improves glucose tolerance and insulin sensitivity in mice. Nutr. Diabetes 2017, 7, 2. [CrossRef] [PubMed]

146. Pedersen, B.K.; Febbraio, M.A. Muscles, exercise and obesity: Skeletal muscle as a secretory organ. Nat. Rev. Endocrinol. 2012, 8 , 457-465. [CrossRef] [PubMed]

147. Lewitt, M.S.; Dent, M.S.; Hall, K. The Insulin-Like Growth Factor System in Obesity, Insulin Resistance and Type 2 Diabetes Mellitus. J. Clin. Med. 2014, 3, 1561-1574. [CrossRef] [PubMed]

148. Mason, C.; Xiao, L.; Duggan, C.; Imayama, I.; Foster-Schubert, K.E.; Kong, A.; Campbell, K.L.; Wang, C.Y.; Alfano, C.M.; Blackburn, G.L.; et al. Effects of dietary weight loss and exercise on insulin-like growth factor-I and insulin-like growth factorbinding protein-3 in postmenopausal women: A randomized controlled trial. Cancer Epidemiol. Biomark. Prev. 2013, 22, 1457-1463. [CrossRef]

149. Thomas, M.; Langley, B.; Berry, C.; Sharma, M.; Kirk, S.; Bass, J.; Kambadur, R. Myostatin, a negative regulator of muscle growth, functions by inhibiting myoblast proliferation. J. Biol. Chem. 2000, 275, 40235-40243. [CrossRef]

150. McCroskery, S.; Thomas, M.; Maxwell, L.; Sharma, M.; Kambadur, R. Myostatin negatively regulates satellite cell activation and self-renewal. J. Cell Biol. 2003, 162, 1135-1147. [CrossRef]

151. Park, J.J.; Berggren, J.R.; Hulver, M.W.; Houmard, J.A.; Hoffman, E.P. GRB14, GPD1, and GDF8 as potential network collaborators in weight loss-induced improvements in insulin action in human skeletal muscle. Physiol. Genom. 2006, 27, 114-121. [CrossRef]

152. Milan, G.; Dalla Nora, E.; Pilon, C.; Pagano, C.; Granzotto, M.; Manco, M.; Mingrone, G.; Vettor, R. Changes in muscle myostatin expression in obese subjects after weight loss. J. Clin. Endocrinol. Metab. 2004, 89, 2724-2727. [CrossRef]

153. Czaja, W.; Nakamura, Y.K.; Li, N.; Eldridge, J.A.; DeAvila, D.M.; Thompson, T.B.; Rodgers, B.D. Myostatin regulates pituitary development and hepatic IGF1. Am. J. Physiol. Endocrinol. Metab. 2019, 316, E1036-E1049. [CrossRef] [PubMed]

154. Williams, N.G.; Interlichia, J.P.; Jackson, M.F.; Hwang, D.; Cohen, P.; Rodgers, B.D. Endocrine actions of myostatin: Systemic regulation of the IGF and IGF binding protein axis. Endocrinology 2011, 152, 172-180. [CrossRef] [PubMed]

155. Guo, T.; Bond, N.D.; Jou, W.; Gavrilova, O.; Portas, J.; McPherron, A.C. Myostatin inhibition prevents diabetes and hyperphagia in a mouse model of lipodystrophy. Diabetes 2012, 61, 2414-2423. [CrossRef] [PubMed]

156. McPherron, A.C.; Lee, S.J. Suppression of body fat accumulation in myostatin-deficient mice. J. Clin. Investig. 2002, 109, 595-601. [CrossRef]

157. Bertrand, C.; Valet, P.; Castan-Laurell, I. Apelin and energy metabolism. Front. Physiol. 2015, 6, 115. [CrossRef]

158. Besse-Patin, A.; Montastier, E.; Vinel, C.; Castan-Laurell, I.; Louche, K.; Dray, C.; Daviaud, D.; Mir, L.; Marques, M.A.; Thalamas, C.; et al. Effect of endurance training on skeletal muscle myokine expression in obese men: Identification of apelin as a novel myokine. Int. J. Obes. 2014, 38, 707-713. [CrossRef]

159. Jang, S.H.; Paik, I.Y.; Ryu, J.H.; Lee, T.H.; Kim, D.E. Effects of aerobic and resistance exercises on circulating apelin-12 and apelin-36 concentrations in obese middle-aged women: A randomized controlled trial. BMC Womens Health 2019, 19, 23. [CrossRef]

160. Ferrante, C.; Orlando, G.; Recinella, L.; Leone, S.; Chiavaroli, A.; Di Nisio, C.; Shohreh, R.; Manippa, F.; Ricciuti, A.; Vacca, M.; et al Central apelin-13 administration modulates hypothalamic control of feeding. J. Biol. Regul. Homeost Agents 2016, 30, 883-888.

161. Valle, A.; Hoggard, N.; Adams, A.C.; Roca, P.; Speakman, J.R. Chronic central administration of apelin-13 over 10 days increases food intake, body weight, locomotor activity and body temperature in C57BL/ 6 mice. J. Neuroendocr. 2008, 20, 79-84.

162. Lin, F.; Wu, H.; Chen, H.; Xin, Z.; Yuan, D.; Wang, T.; Liu, J.; Gao, Y.; Zhang, X.; Zhou, C.; et al. Molecular and physiological evidences for the role in appetite regulation of apelin and its receptor APJ in Ya-fish (Schizothorax prenanti). Mol. Cell Endocrinol. 2014, 396, 46-57. [CrossRef]

163. Heinonen, M.V.; Purhonen, A.K.; Miettinen, P.; Pääkkönen, M.; Pirinen, E.; Alhava, E.; Akerman, K.; Herzig, K.H. Apelin, orexin-A and leptin plasma levels in morbid obesity and effect of gastric banding. Regul. Pept. 2005, 130, 7-13. [CrossRef] [PubMed]

164. Kiskac, M.; Zorlu, M.; Cakirca, M.; Karatoprak, C.; Kesgin, S.; Büyükaydın, B.; Yavuz, E.; Ardic, C.; Camli, A.A.; Cikrikcioglu, M.A. Evaluation of the relationship between serum apelin levels and vitamin $\mathrm{D}$ and mean platelet volume in diabetic patients. Ann. Endocrinol. 2014, 75, 200-205. [CrossRef]

165. Krist, J.; Wieder, K.; Klöting, N.; Oberbach, A.; Kralisch, S.; Wiesner, T.; Schön, M.R.; Gärtner, D.; Dietrich, A.; Shang, E.; et al. Effects of weight loss and exercise on apelin serum concentrations and adipose tissue expression in human obesity. Obes. Facts. 2013, 6, 57-69. [CrossRef] [PubMed]

166. Soriguer, F.; Garrido-Sanchez, L.; Garcia-Serrano, S.; Garcia-Almeida, J.M.; Garcia-Arnes, J.; Tinahones, F.J.; Garcia-Fuentes, E. Apelin levels are increased in morbidly obese subjects with type 2 diabetes mellitus. Obes. Surg. 2009, 19, 1574-1580. [CrossRef] [PubMed]

167. Drougard, A.; Fournel, A.; Marlin, A.; Meunier, E.; Abot, A.; Bautzova, T.; Duparc, T.; Louche, K.; Batut, A.; Lucas, A.; et al. Central chronic apelin infusion decreases energy expenditure and thermogenesis in mice. Sci. Rep. 2016, 6, 31849. [CrossRef] [PubMed]

168. Gilbert, W.; Bragg, R.; Elmansi, A.M.; McGee-Lawrence, M.E.; Isales, C.M.; Hamrick, M.W.; Hill, W.D.; Fulzele, S. Stromal cell-derived factor-1 (CXCL12) and its role in bone and muscle biology. Cytokine 2019, 123, 154783. [CrossRef] 
169. Banisadr, G.; Skrzydelski, D.; Kitabgi, P.; Rostène, W.; Parsadaniantz, S.M. Highly regionalized distribution of stromal cell-derived factor-1/CXCL12 in adult rat brain: Constitutive expression in cholinergic, dopaminergic and vasopressinergic neurons. Eur. J. Neurosci. 2003, 18, 1593-1606. [CrossRef]

170. Kim, D.; Kim, J.; Yoon, J.H.; Ghim, J.; Yea, K.; Song, P.; Park, S.; Lee, A.; Hong, C.P.; Jang, M.S.; et al. CXCL12 secreted from adipose tissue recruits macrophages and induces insulin resistance in mice. Diabetologia 2014, 57, 1456-1465. [CrossRef]

171. Poon, K.; Barson, J.R.; Ho, H.T.; Leibowitz, S.F. Relationship of the Chemokine, CXCL12, to Effects of Dietary Fat on FeedingRelated Behaviors and Hypothalamic Neuropeptide Systems. Front Behav. Neurosci. 2016, 10, 51. [CrossRef]

172. Emmons, R.; Niemiro, G.M.; Owolabi, O.; De Lisio, M. Acute exercise mobilizes hematopoietic stem and progenitor cells and alters the mesenchymal stromal cell secretome. J. Appl. Physiol. 2016, 120, 624-632. [CrossRef]

173. Wang, J.S.; Lee, M.Y.; Lien, H.Y.; Weng, T.P. Hypoxic exercise training improves cardiac/muscular hemodynamics and is associated with modulated circulating progenitor cells in sedentary men. Int. J. Cardiol. 2014, 170, 315-323. [CrossRef]

174. Wolf, R.M.; Jaffe, A.E.; Steele, K.E.; Schweitzer, M.A.; Magnuson, T.H.; Wolfe, A.; Wong, G.W. Cytokine, Chemokine, and Cytokine Receptor Changes Are Associated With Metabolic Improvements After Bariatric Surgery. J. Clin. Endocrinol. Metab. 2019, 104, 947-956. [CrossRef]

175. Piccirillo, R. Exercise-Induced Myokines With Therapeutic Potential for Muscle Wasting. Front. Physiol 2019, 10, 287. [CrossRef]

176. Garito, T.; Roubenoff, R.; Hompesch, M.; Morrow, L.; Gomez, K.; Rooks, D.; Meyers, C.; Buchsbaum, M.S.; Neelakantham, S.; Swan, T.; et al. Bimagrumab improves body composition and insulin sensitivity in insulin-resistant individuals. Diabetes Obes. Metab. 2018, 20, 94-102. [CrossRef]

177. Hanna, M.G.; Badrising, U.A.; Benveniste, O.; Lloyd, T.E.; Needham, M.; Chinoy, H.; Aoki, M.; Machado, P.M.; Liang, C.; Reardon, K.A.; et al. Safety and efficacy of intravenous bimagrumab in inclusion body myositis (RESILIENT): A randomised, double-blind, placebo-controlled phase $2 \mathrm{~b}$ trial. Lancet Neurol. 2019, 18, 834-844. [CrossRef]

178. Heymsfield, S.B.; Coleman, L.A.; Miller, R.; Rooks, D.S.; Laurent, D.; Petricoul, O.; Praestgaard, J.; Swan, T.; Wade, T.; Perry, R.G.; et al. Effect of Bimagrumab vs Placebo on Body Fat Mass among Adults with Type 2 Diabetes and Obesity: A Phase 2 Randomized Clinical Trial. JAMA Netw. Open 2021, 4, e2033457. [CrossRef]

179. Fournier, B.; Murray, B.; Gutzwiller, S.; Marcaletti, S.; Marcellin, D.; Bergling, S.; Brachat, S.; Persohn, E.; Pierrel, E.; Bombard, F.; et al. Blockade of the activin receptor IIb activates functional brown adipogenesis and thermogenesis by inducing mitochondrial oxidative metabolism. Mol. Cell Biol. 2012, 32, 2871-2879. [CrossRef] 